\title{
Konstruksi alat ukur karakter nasionalisme
}

\author{
Nofrans Eka Saputra \\ Program Studi Psikologi, Fakultas Kedokteran dan Ilmu Kesehatan, Universitas Jambi \\ nofransekasaputra@unja.ac.id \\ Yun Nina Ekawati \\ Program Studi Psikologi, Fakultas Kedokteran dan Ilmu Kesehatan, Universitas Jambi \\ yun_nina.e@unja.ac.id \\ Rahmadhani Islamiah \\ Program Studi Psikologi, Fakultas Kedokteran dan Ilmu Kesehatan, Universitas Jambi \\ rahmadhanimia@gmail.com
}

\begin{abstract}
ABSTRAK
Tujuan penelitian ini adalah melakukan validitas konstruk dengan menggunakan analisis faktor pada alat ukur karakter, khususnya karakter nasionalisme. Populasi penelitian ini adalah siswa Sekolah Menengah Atas (SMA). Jumlah sampel yang digunakan sebanyak 337 responden, dengan teknik pengambilan sampel dengan purposive sampling di setiap wilayah yaitu pada SMA 1 Kabupaten Kerinci, SMA Negeri 1 Tanjung Jabung Barat, SMA Negeri 5 Kota Kabupaten Tebo dan SMA Negeri 12 Kabupaten Merangin, dan SMA Negeri 1 Kota Jambi dengan rentang usia 15 hingga 18 tahun. Hasil penelitian ini menunjukkan bahwa validitas konstruk yang menggunakan analisis Principal Component Analysis dengan rotasi orthogonal dan ekstraksi varimaks menghasilkan lima faktor yang berhasil diekstraksi yang berupa komponen cinta tanah air, menghargai keragaman budaya, apresiasi budaya bangsa, taat hukum, serta unggul dan berprestasi. Hasil uji reliabilitas konsistensi internal dengan Metode Guttman $\lambda=0.862$. Norma alat ukur menggunakan standar deviasi hipotetik baik untuk setiap komponen maupun alat ukur keseluruhan. Alat ukur ini didukung oleh validitas konstruk yang baik serta reliabilitas yang memuaskan.

Kata Kunci: Karakter Nasionalisme, Kontruksi Alat Ukur, Reliabilitas, Siswa Sekolah Menengah Atas, Validitas
\end{abstract}

\begin{abstract}
The aim of this research is to conduct validity constract by using factor analysis in the character measuring instrument, in particular character of nasionalism. The population of this research is senior high school students. The number of sample used is 337 respondents, by using purposive sampling technique for each regions including SMA 1 Kerinci regency, SMA 1 West Tanjung Jabung regency, SMA 5 Tebo Regency, SMA 12 Merangin Regency and SMA 1 Jambi City by the age of 15 to 18 years old. The result of this research reveals that validity construct which using Principal Component Analysis with orthogonal rotation and varimaks ekstraction generated five factors that has been successfully extracted to be some components including loving the country, appreciating the cultural diversity, appreciating national culture, obeying the law and being excellent and having achievement. The result of the internal consistency realiability test by using Guttman Method $\lambda=0.862$. The measuring instrument norm by using hypothetical deviation standard for both each component and overall measuring instrument. This measuring instrument is supported by good validity construct and satisfying reliability.
\end{abstract}


Jurnal Psikologi Terapan dan Pendidikan

ISSN: $2715-2456$

Vol. 1, No. 2, November 2019, pp. 63-98

Keywords: Measuring Instrument Construction, Nasionalism Character, Reliability, Senior High School Students, Validity

\section{PENDAHULUAN}

Menurut Scerenko karakter merupakan atribut atau suatu karakteristik yang membentuk dan membedakan individu dari individu yang lain, ciri etis, maupun kompleksitas mental individu, kelompok, ataupun bangsa (Samani \& Hariyanto, 2012). Karakter dalam pemahaman tokoh bangsa Indonesia diartikan sebagai suatu perangkat nilai yang berasal dari norma agama, hukum, sosial, budaya, adat istiadat, serta estetika yang terealisasi dalam pikiran, perasaan, sikap, perkataan, serta perbuatan yang mendasari perilaku manusia dalam melaksanakan hal-hal yang berkaitan dengan asas Ketuhanan Yang Maha Esa, hubungan dengan diri sendiri atau dengan orang lain, lingkungan, maupun kebangsaan. Hal ini menjelaskan bahwa karakter merupakan aspek penting pada individu dalam menjalankan fungsinya sebagai seorang manusia. Implikasi lain dari karakter ini dapat membentuk dan menjadi identitas bagi suatu bangsa (identitas nasional). Identitas inilah yang menjadi tolak ukur maupun 'wajah' dari bangsa Indonesia yang plural.

Nasionalisme merupakan suatu paham yang berkaitan dengan kesadaran bahwa setiap warga negara merupakan bagian dari bangsa Indonesia oleh karenanya setiap individu memiliki kewajiban untuk mencintai dan turut membela negaranya (Permanto, 2012). Paham nasionalisme tersebut masih sangat luas serta dapat diaktualisasikan dalam banyak definisi maupun perilaku. Salah satunya oleh Sadikin (Ratnasari, 2017) yang mengaktualisasikan nasionalisme sebagai suatu sikap cinta terhadap tanah air atau bangsa dan negara sebagai perwujudan dari cita-cita dan tujuan yang diikat oleh sikap-sikap politik, ekonomi, sosial, serta budaya sebagai bentuk persatuan dan kemerdekaan nasional dengan prinsip kebebasan dan kesamarataan kehidupan bermasyarakat dan bernegara. Berdasarkan pengertian tersebut dapat dipahami jika nasionalisme dapat menjadi suatu cara atau jalan untuk dapat mengatasi berbagai permasalahan kebangsaan dan kenegaraan. Sehingga penting bagi setiap inidividu untuk memiliki rasa ataupun sikap nasionalisme itu.

Saat ini Indonesia dapat dikatakan mengalami krisis nasionalisme. Dimana isu-isu mengenai gerakan separatis, anarkis, kekerasan, penyimpangan sosial, radikalisme yang melunturkan semangat kesatuan dan persatuan. Dalam contoh sederhana dimana tumbuhnya rasa kebanggaan untuk mengikuti budaya popular serta adanya gaya hidup hedonism pada diri warga negara melunturkan rasa bangga dan cinta terhadap tanah air - ini dikarenakan adanya keengganan oleh warga negara untuk mengenal jati diri bangsanya. Krisis nasionalisme yang sangat dirasakan saat ini adalah adanya intoleransi beragama maupun primodialisme. Hal ini dapat disebabkan oleh kepentingan kelompok atau bahkan politik tertentu, dimana konflik yang dihasilkan dapat melunturkan semangat serta sikap nasionalisme bangsa Indonesia. 
Jurnal Psikologi Terapan dan Pendidikan

ISSN: $2715-2456$

Vol. 1, No. 2, November 2019, pp. 63-98

Oleh karena itu penting bagi seorang siswa untuk mendapatkan pendidikan karakter nasionalisme untuk menanamkan nilai-nilai nasionalisme tersebut dan menjadi seperangkat nilai moral bagi siswa dalam berperilaku.

Pada dasarnya penanaman karakter menjadi tugas fundamental orangtua ataupun keluarga di rumah. Namun dalam beberapa hal penanaman karakter akan lebih komprehensif melalui pendidikan karakter yang terintegrasi di sekolah. Hal ini dikarenakan lingkungan sekolah yang memfasilitasi kemajemukan pada individu. Selain itu adanya keberagaman dilingkungan sekolah menuntut anak untuk belajar bersikap toleran yang secara tidak langsung memupuk sikap nasionalisme.

Pendidikan karakter merupakan usaha yang dilakukan oleh warga sekolah secara bersama-sama dimulai dari guru sebagai tenaga pendidik yang professional hingga ke siswa sebagai pelajar untuk mewujudkan dan menciptakan suatu budaya baru disekolah yang memiliki pengaruh terhadap karakter siswa yang dididik. Pendidikan karakter pada dasarnya telah menjadi pilot project pemerintahan Indonesia saat ini melalui program Penguatan Pendidikan Karakter dengan mengusung lima nilai karakter utama yang wajib dimiliki dan dibangun dalam diri siswa-siswi sekolah dasar hingga menengah atas. Namun aktualisasi dari efektivitas program tersebut masih belum sepenuhnya dapat dijelaskan sejauh mana perubahan pada karakter siswa-siswi tersebut baik secara individual ataupun kolektif. Sehingga hal ini akan mempengaruhi pembentukan karakter yang diharapkan,

Tujuan dari penelitian ini adalah untuk membuat kontruksi skala karakter nasionalisme pada anak Sekolah Menengah Atas (SMA) serta melakukan uji validitas terhadap konstruk menggunakan analisis komponen. Penggunaan analisis komponen dalam pengujian validitas konstruk dilakukan karena pada dasarnya karakter terutama karakter nasionalisme merupakan atribut psikologis yang abstrak untuk didefinisikan, sehingga dengan melakukan analisis komponen terhadap indikator karakter nasionalisme yang diusung oleh Kemendikbud akan didapatkan dasar konsep atau definisi yang jelas, komprehensif, dan konkrit mengenai konstruk karakter nasionalisme serta sesuai dengan kepribadian dan jati diri bangsa Indonesia. Selain itu tujuan lain dari membuat alat ukur ini adalah untuk membuat skala karakter nasionalisme pada siswa SMA yang terstandar sehingga dapat digunakan untuk berbagai kepentingan baik asesmen kepribadian maupun sebagai salah satu rangkaian yang melengkapi rangkaian tes psikologis lainnya.

\section{METODE PENELITIAN}

Penelitian ini dilakukan dengan beberapa tahapan prosedur: 1) Kontruksi alat ukur karakter nasionalime, 2) Analisis properti psikometris skala. Pelaksanaan tahapan prosedur tersebut bertujuan 
Jurnal Psikologi Terapan dan Pendidikan

ISSN: $2715-2456$

Vol. 1, No. 2, November 2019, pp. 63-98

untuk mendapatkan skala psikologi yang baik yaitu valid, reliabel, dan terstandar juga memudahkan peneliti dalam membuat analisa laporan lebih sistematis.

Kontruksi alat ukur nasionalisme ini dilakukan dengan beberapa tahapan, tahapan pertama, Penetapan Konstruk, Komponen dan Indikator Perilaku; Kontruksi alat ukur diawali dengan menetapkan konstruk yang diukur yaitu konstruk karakter nasionalisme. Review konstruk dan komponen dilakukan melalui studi literatur yang mengacu pada beberapa buku cetak, jurnal, dan sumber literatur lainnya yang membahas mengenai karakter nasionalis pada siswa sekolah menengah atas. Studi literatur ini didapatkan beberapa komponen penyusun konstruk, diantaranya: apresiasi budaya, kekayaan budaya, rela berkorban, unggul dan berprestasi cinta tanah air, menjaga lingkungan, taat hukum, disiplin, dan keragaman budaya. Masing-masing komponen diturunkan kedalam beberapa indikator perilaku yang menjadi blue print dalam penulisan aitem. Sebelum melakukan penulisan aitem maka komponen dan indikator direview terlebih dahulu oleh orang yang memiliki keahlian dibidang tersebut dalam sebuah panel diskusi melalui prosedur focus group discussion (FGD) terhadap beberapa ahli konstrak yang memahami konstrak nasionalisme dan ahli psikologi perkembangan manusia. Pelaksanaan FGD diperlukan mengingat konstrak yang akan dibangun berdasarkan konsep Penguatan Pendidikan Karakter Kemdikbud bukanlah konsep konkrit sehingga diperlukan perumusan agar menghasilkan blue print konstrak yang padat dan konkrit yang selanjutnya akan memudahkan penulisan aitem. Tahapan review ahli dilakukan sebelum dan setelah tahapan penulisan aitem Tahapan ini serta pelaksanaan review terhadap ahli dibidangnya akan menentukan validitas internal dari konstruk skala yang akan dibuat.

Tahap kedua, menentukan format penskalaan: Penskalaan merupakan proses penentuan letak kategori respon responden terhadap pernyataan aitem yang telah dibuat dalam suatu kontinum psikologis yang telah ditentukan (Azwar, 2017). Penentuan format penskalaan ini akan menentukan bagaimana penentuan nilai yang akan diberikan. Dalam kontruksi skala ini, format penskalaan yang dipilih adalah model skala likert dengan 4 jenjang nilai, yaitu Sangat Setuju (SS), Setuju (S), Tidak Setuju (TS), dan Sangat Tidak Setuju (STS).

Tahap ketiga, Penulisan aitem. Setelah merumuskan komponen dan indikator konstruk kedalam blue print, peneliti membuat aitem sesuai dengan proporsi aitem yang telah ditentukan. Dalam penulisan aitem awal yang akan di uji coba didapatkan 27 aitem pernyataan yang terdiri dari aitem favorabel dan unfavorabel. Item yang telah dibuat di review kembali oleh peneliti, rekan peneliti, ahli konstruk, subjek sampel dan ahli tata bahasa sebelum dilaksanakan uji coba aitem kepada kelompok subjek. Tujuannya adalah untuk mencapai validitas logis dari alat ukur ini, apakah aitem telah mengungkap hal sesuai 
Jurnal Psikologi Terapan dan Pendidikan

ISSN: 2715-2456

Vol. 1, No. 2, November 2019, pp. 63-98

indikator yang telah ditetapkan, apakah subjek dapat mengerti apa yang dimaksud dalam aitem pernyataan, apakah penulisan telah sesuai dengan ejaan bahasa Indonesia yang baik dan benar.

Analisis properti psikometris ini dilakukan setelah mendapatkan data dari uji coba alat ukur yang telah dilakukan. Analisis konstruk yang digunakan adalah uji validitas faktorial dengan metode Principal Component Analysis (PCA) rotasi orthoghonal dan ekstraksi varimaks. PCA bertujuan untuk meringkas pola korelasi antara observed variables, untuk mengurangi sejumlah besar observed variables kedalam sejumlah kecil faktor untuk memberikan definisi operasional (persamaan regresi) untuk proses yang mendasarinya dengan menggunakan observed variables (Tabachnick \& Fidell, 2014). PCA melakukan analisis menggunakan korelasi terhadap sejumlah data observed variables yang memenuhi syarat analisis kemudian mereduksinya. Secara empiris teknik statistika yang digunakan dalam analisis PCA menemukan dan merangkum observed variables yang saling berkorelasi dalam satu himpunan menjadi satu komponen utama. Setiap komponen yang terbentuk akan tidak bergantung (independen) dengan komponen lainnya sehingga setiap komponen dinilai masing-masing (tersendiri) tanpa dikaitkan dengan komponen lainnya. Kemudian dilakukan ekstraksi varimaks untuk menganalisa keterbentukan faktorfaktor terhadap sekumpulan komponen yang ada. Uji Reliabilitas alat ukur dilakukan dengan menggunakan metode Gutmann's. Pembuatan norma dan interpretasi yaitu dengan membuat norma hipotetik baik untuk skoring skala keseluruhan maupun skoring skala per komponen.

Subjek berjumlah 337 responden dengan teknik pengambilan sampel penelitian random sampling terhadap siswa/i sekolah menengah atas yang tersebar di Provinsi Jambi, diantaranya; SMAN 1 Kabupaten Kerinci, SMAN 1 Tanjung Jabung Barat, SMAN 5 Kabupaten Tebo, SMAN 12 Kabupaten Merangin, dan SMAN 1 Kota Jambi.

\section{HASIL DAN PEMBAHASAN}

Hasil dari pelaksanaan metode penelitian kontruksi alat ukur karakter nasionalisme ini adalah: 1) Skala karakter nasionalisme final, 2) Nilai property psikometris yang mendukung validitas dan reliabilitas karakter nasionalisme, serta 3) Norma dan interpretasi skala.

\section{Skala Karakter Nasionalisme Final}

Uji Validitas Faktorial

Komponen skala karakter nasionalisme final ini didapatkan melalui uji analisis properti psikometris pertama terhadap hasil data uji coba alat ukur. Uji validitas faktorial konstruk dilakukan dengan menggunakan metode analisis Principal Component Analysis (PCA). Validitas faktor merupakan validitas yang didapat melalui analisis terhadap faktor pembentuk alat ukur. Principal Component 
Jurnal Psikologi Terapan dan Pendidikan

ISSN: $2715-2456$

Vol. 1, No. 2, November 2019, pp. 63-98

Analysis (PCA) merupakan teknik yang digunakan untuk melihat atau mengkonfirmasi faktor-faktor yang membentuk suatu konstruk skala dengan cara mereduksi komponen suatu data tanpa mengurangi karakteristik konstruk skala secara signifikan. Teknik PCA lebih dipilih karena menurut Stevans PCA dapat menghindari masalah ketidakpastian faktor atau komponen yang terbentuk yang biasa ditemukan dalam analisis faktor lainnya (Harrington, 2009).

Metode PCA ini dapat mengumpulkan aitem-aitem awal menjadi suatu komponen baru dengan menganalisis semua varians pada observed variabels dan membentuk komponen baru hasil reduksi variabel. Komponen baru hasil analisis PCA menjadi komponen yang lebih kecil dan spesifik serta tidak saling berkorelasi. Hal itu berarti komponen-komponen baru hasil analisis PCA merupakan komponen yang berdiri sendiri dan saling bebas.

Menggunakan Principal Component Analysis (PCA) sebagai analisis properti psikometris akan memberikan aitem terbaik dalam penyusunan alat ukur final. Item tersebut menggambarkan hal yang sebenarnya dalam alat ukur. Dikarenakan analisis komponen ini akan mengumpulkan aitem-aitem serumpun berkumpul pada satu komponen tertentu, sehingga ini akan mempermudah peneliti dalam melakukan penyusunan alat ukur final.

Berdasarkan analisis rotasi orthoghonal dan ekstraksi varimaks dari 9 komponen yang dirumuskan menghasilkan aitem-aitem yang mengelompok pada 5 komponenutama baru. Setiap komponen baru yang terbentuk merupakan gabungan dari beberapa observed variable yang memiliki korelasi dengan komponen pembentuknya. Komponen baru yang terbentuk melalui hasil analisis PCA menghasilkan jumlah komponen yang sedikit namun mencakup seluruh informasi yang berkaitan dengan komponen berdasarkan observed variables yang melandasinya. Analisis ini menghilangkan korelasi antar komponen yang terbentuk sehingga masing-masing komponen tersebut saling berdiri sendiri dan tidak saling mempengaruhi.

Komponen utama yang pertama terdiri dari aitem-aitem rela berkorban, cinta tanah air, menjaga lingkungan, taat hukum, dan disiplin sebagai observed variables yang membentuk komponen. Komponen utama kedua terbentu dari aitem-aitem unggul dan menghormati keragaman budaya, suku, dan agama sebagai observed variables yang membentuk komponen. Komponen utama ketiga terbentuk dari aitemaitem apresiasi budaya bangsa dan menjaga kekayaan budaya budaya bangsa sebagai observed variables yang membentuk komponen. Komponen utama keempat terbentuk dari aitem-aitem rela berkorban, taat hukum, dan disiplin sebagai observed variables yang membentuk komponen. Komponen utama kelima terbentuk dari aitem-aitem menjaga kekayaan budaya bangsa serta aitem unggul dan berprestasi sebagai observed variables yang membentuk komponen. 
Jurnal Psikologi Terapan dan Pendidikan

ISSN: $2715-2456$

Vol. 1, No. 2, November 2019, pp. 63-98

Pengelompokan tersebut terjadi karena beberapa faktor seperti aitem-aitem yang dibuat pada observed variables tertentu memiliki kemiripan dengan observed variables atau memiliki keterkaitan antara satu dan lainnya sehingga tidak terdapat perbedaan yang signifikan antar komponen tersebut sehingga aitem-aitem dari berbagai observed variables tersebut mengelompok membentuk satu komponen utama yang baru. Faktor lain yang menyebabkan mengumpulnya aitem-aitem pada satu komponen adalah bahwa beberapa observed variables berasal dari satu komponen utama yang sama sehingga peneliti dapat memberikan satu pengertian atau definisi baru mengenai komponen tersebut. Terlebih sub nilai sebagai indikator yang mendasari nilai karakter utama pada PPK terdapat tumpang tindih antara satu sub nilai dengan sub nilai lain, baik yang terdapat pada satu nilai karakter maupun nilai karakter yang lainnya.

Dengan melakukan analisis faktorial menggunakan teknik Principal Component Analysis (PCA) ini, maka komponen final yang dihasilkan adalah komponen yang telah direduksi berdasarkan kesamaan karakteristiknya menjadi komponen utama yang signifikan sebagai penyusun konstruk serta antar komponen tidak saling berhubungan lagi melainkan berdiri sendiri (independen). Oleh karena itu peneliti harus memberikan label dan definisi baru terhadap komponen baru tersebut, dimana komponen pertama peneliti definisikan sebagai komponencinta tanah air, komponen kedua sebagai komponen menghormati keragaman budaya, komponen ketiga sebagai komponen apresiasi budaya bangsa, komponen keempat disebut sebagai komponen taat hukum, dan komponen kelima sebagai komponen unggul dan berprestasi. Analisis faktorial dengan PCA ini dilakukan menggunakan aplikasi statistic pada aplikasi statistik JASP 0.9.0.0. Hasil analisis faktor tersebut digambarkan dalam tabel 1 berikut.

Tabel 1.

Hasil Analisis Faktor Alat ukur Karakter Nasionalis

\begin{tabular}{|c|c|c|c|c|c|}
\hline & $\begin{array}{c}\text { Cinta Tanah } \\
\text { Air }\end{array}$ & $\begin{array}{l}\text { Menghormati } \\
\text { Keragaman } \\
\text { Budaya }\end{array}$ & $\begin{array}{c}\text { Apresiasi } \\
\text { Budaya Bangsa }\end{array}$ & $\begin{array}{c}\text { Taat } \\
\text { Hukum }\end{array}$ & $\begin{array}{l}\text { Unggul \& } \\
\text { Berprestasi }\end{array}$ \\
\hline $\begin{array}{l}\text { Nomor } \\
\text { Aitem }\end{array}$ & $\begin{array}{l}40,46,47,48, \\
49,50,51,52, \\
53,55,56\end{array}$ & $44,58,59,60$ & $34,35,36,37$ & $\begin{array}{l}41, \quad 42, \\
54,57\end{array}$ & 45,39 \\
\hline
\end{tabular}

Dalam penyusunan skala final, dari 27 aitem awal yang telah dibuat direduksi menjadi 25 aitem. Aitem ini didapat dari aitem yang lolos melalui analisis faktorial dengan nilai koefisien muatan faktor dimulai dari 0.411 sampai dengan 0.747 yang berarti aitem memiliki hubungan yang cukup hingga sangat baik sebagai observed variables yang mendasari komponen utama. Hal itu berarti aitem skala karakter nasionalis memiliki kemampuan yang tinggi untuk mengukur karakter-karakter yang mendasari nasionalisme siswa SMA. 
Tabel 2.

Nilai Koefisien Component Loading

\begin{tabular}{|c|c|c|c|c|c|c|c|}
\hline \multirow[t]{2}{*}{ Aitem } & \multirow[t]{2}{*}{ Pernyataan } & \multicolumn{5}{|c|}{ Component Loading } & \multirow{2}{*}{$\begin{array}{l}\text { Uniqu } \\
\text { eness }\end{array}$} \\
\hline & & $\mathbf{I}$ & II & III & IV & $\mathbf{V}$ & \\
\hline 40 & Saya berupaya menjadi bagian... & 0.417 & & & & & 0.651 \\
\hline 46 & $\begin{array}{l}\text { Saya berupaya berbahasa } \\
\text { Indonesia... }\end{array}$ & 0.628 & . & . & . & . & 0.572 \\
\hline 47 & Ketika upacara bendera saya... & 0.523 & . & . & . & . & 0.515 \\
\hline 48 & $\begin{array}{l}\text { Saya menggunakan bahasa } \\
\text { derah... }\end{array}$ & 0.411 & . & . & . & . & 0.643 \\
\hline 49 & Saya berupaya turut serta... & 0.567 & . & . & . & . & 0.567 \\
\hline 50 & Saya menjadi bagian penting... & 0.586 & . & . & . & . & 0.496 \\
\hline 51 & $\begin{array}{l}\text { Kebanyakan siswa masa } \\
\text { bodoh... }\end{array}$ & 0.513 & . & . & . & . & 0.548 \\
\hline 52 & $\begin{array}{l}\text { Saya mengingatkan teman- } \\
\text { teman... }\end{array}$ & 0.680 & . & . & . & . & 0.495 \\
\hline 53 & $\begin{array}{l}\text { Setiap tugas dikumpulkan tepat } \\
\text { waktu }\end{array}$ & 0.482 & . & . & . & . & 0.430 \\
\hline 55 & $\begin{array}{l}\text { Saya menggunakan saragam } \\
\text { lengkap... }\end{array}$ & 0.504 & . & . & . & . & 0.725 \\
\hline 56 & Saya tidak pernah lalai... & 0.565 & & . & . & . & 0.648 \\
\hline 44 & $\begin{array}{l}\text { Saya meningkatkan } \\
\text { kemampuan... }\end{array}$ & . & 0.409 & . & . & . & 0.641 \\
\hline 58 & Saya merasa bangga berteman... & . & 0.740 & . & . & . & 0.394 \\
\hline 59 & Saya tetap peduli dengan... & . & 0.598 & . & . & . & 0.503 \\
\hline 60 & Saya lebih memilih teman... & . & 0.647 & . & . & . & 0.501 \\
\hline 34 & $\begin{array}{l}\text { Saya berupaya mengetahui } \\
\text { lagu... }\end{array}$ & . & . & 0.682 & . & . & 0.419 \\
\hline 35 & $\begin{array}{l}\text { Saya kagum terhadap tarian- } \\
\text { tarian... }\end{array}$ & . & . & 0.723 & . & . & 0.409 \\
\hline 36 & Saya cenderung masa bodoh... & . & . & 0.480 & . & . & 0.580 \\
\hline 37 & $\begin{array}{l}\text { Saya merasa perlu } \\
\text { mempertahankan... }\end{array}$ & . & . & 0.562 & . & . & 0.523 \\
\hline 41 & $\begin{array}{l}\text { Saya mendahulukan kepentingan } \\
\text { orang... }\end{array}$ & . & . & . & 0.645 & . & 0.510 \\
\hline 42 & $\begin{array}{l}\text { Saya lebih terbiasa } \\
\text { mementingkan... }\end{array}$ & . & . & . & 0.747 & . & 0.394 \\
\hline 54 & Lebih baik terlambat sekolah... & . & . & . & 0.451 & . & 0.650 \\
\hline 57 & Saya merasa nyaman tidak... & . & . & . & 0.449 & . & 0.720 \\
\hline 39 & Saya kurang tertarik dalam... & . & . & . & . & 0.663 & 0.534 \\
\hline 45 & Prestasi yang dicapai teman... & & 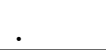 & & & 0.607 & 0.513 \\
\hline
\end{tabular}

\section{Analisis Properti Psikometris}

Validitas Konstrak 
Untuk melengkapi analisis properti psikometris skala karakter nasionalisme pada remaja SMA ini, peneliti melakukan uji validitas konstrak. Menurut Azwar pengujian terhadap validitas konstrak ini dilakukan untuk mengetahui sejauh mana alat ukur mampu mengukur konstrak teoretik yang akan diukur (Periantalo, 2015). Uji validitas konstrak ini dilakukan setelah melakukan uji validitas isi. Uji validitas konstrak yang dilakukan adalah dengan melakukan korelasi antar komponen dalam skala.

Komponen pembentuk skala idealnya akan saling mendukung karena mengungkap hal yang sama dalam alat ukur, namun komponen tersebut bisa saja tidak saling mendukung satu sama lain. Hal tersebut dimungkinkan jika teori atau dasar logika mengatakan bahwa komponen tersebut memang mengungkap hal yang sama, berbeda, atau berlawanan (Periantalo, 2015).

Pada dasarnya ada tiga kemungkinan hasil korelasi antar komponen dalam suatu alat ukur, yaitu mendukung, berbeda, atau berlawanan. Komponen yang saling mendukung akan menunjukkan korelasi positif satu sama lain dan besaran nilai pada suatu komponen akan menunjukkan besaran pada nilai komponen yang lain, hasil ini menunjukkan validitas konvergen. Disisi lain dapat pula terjadi korelasi antar komponen yang saling berbeda atau tidak berhubungan satu sama lain. Jika dikorelasikan maka akan menghasilkan korelasi yang rendah, korelasi seperti ini merupakan hasil dari validitas diskriminan. Pada validitas diskriminan menunjukkan jika tinggi rendahnya suatu komponen tidak ditentukan dengan komponen lainnya, artinya jika individu mendapat skor tinggi pada satu komponen, maka tidak akan ada kaitan atau hubungannya pada komponen yang lain (Periantalo, 2015).

Hal tersebut seperti hasil analisis faktorial dengan metode principal component analisys yang menghasilkan korelasi komponen yang tidak saling berkaitan melainkan berdiri sendiri (saling bebas). Hasil uji validitas konstrak dengan mengkorelasikan komponen pembentuk skala berdasarkan analisis faktor didapat data sebagai berikut.

Tabel 3.

Validitas Faktor

\begin{tabular}{llllll}
\hline & $\begin{array}{l}\text { Cinta } \\
\text { Tanah Air }\end{array}$ & $\begin{array}{l}\text { Menghargai } \\
\text { Keragaman } \\
\text { Budaya }\end{array}$ & $\begin{array}{l}\text { Apresiasi } \\
\text { Budaya Bangsa }\end{array}$ & $\begin{array}{l}\text { Taat } \\
\text { Hukum }\end{array}$ & $\begin{array}{l}\text { Unggul dan } \\
\text { Berprestasi }\end{array}$ \\
\hline $\begin{array}{l}\text { Cinta Tanah } \\
\text { Air }\end{array}$ & 1.000 & $\cdot$ & $\cdot$ & $\cdot$ & $\cdot$ \\
$\begin{array}{l}\text { Menghargai } \\
\text { Keragaman }\end{array}$ & -0.000 & 1.000 & $\cdot$ & $\cdot$ & $\cdot$ \\
$\begin{array}{l}\text { Budaya } \\
\text { Apresiasi }\end{array}$ & -0.000 & 0.000 & 1.000 & $\cdot$ & \\
$\begin{array}{l}\text { Budaya Bangsa } \\
\text { Taat Hukum }\end{array}$ & -0.000 & 0.000 & 0.000 & 1.000 & $\cdot$ \\
$\begin{array}{l}\text { Unggul dan } \\
\text { Berprestasi }\end{array}$ & 0.000 & -0.000 & 0.000 & -0.000 & 1.000 \\
\hline
\end{tabular}

Hasil analisis korelasi komponen tersebut menunjukkan bahwa hubungan antara komponen pembentuk skala karakter nasionalisme memiliki korelasi positif dan negatif antar beberapa komponen. Berdasarkan hasil analisis korelasi antar komponen pembentuk konstrak skala diketahui jika komponen menghargai keragaman budaya, apreasiasi budaya bangsa dan taat hukum memiliki hubungan korelasi 
Jurnal Psikologi Terapan dan Pendidikan

ISSN: $2715-2456$

Vol. 1, No. 2, November 2019, pp. 63-98

yang positif satu sama lain. Komponen unggul dan berprestasi memiliki korelasi positif dengan komponen cinta tanah air dan apresiasi budaya bangsa. Disisi lain pada analisis korelasi antar komponen ini juga terdapat korelasi yang bernilai negatif. Komponen cinta tanah air memiliki korelasi yang negatif dengan komponen menghargai keragaman budaya, apresiasi budaya bangsa, dan taat hukum, begitu juga dengan komponen unggul dan berprestasi dengan komponen menghargai keragaman budaya dan taat hukum. Antar komponen tersebut memiliki koefisien korelasi sebesar 0.00 yang berarti setiap komponen tidak memiliki hubungan yang bermakna apapun, meskipun hasil analisis menunjukkan korelasi yang positif ataupun negatif. Ini dikarenakan analisis data menggunakan analisis PCA, sehingga antar komponen tidak lagi berkorelasi melainkan berdiri sendiri (independen) dan tidak memiliki hubungan dengan komponen pembentuk lainnya. Dengan kata lain jika individu mendapatkan skor tinggi atau rendah pada salah satu komponen, tidak akan mempengaruhi atau berhubungan pada skor komponen lain.

\section{Reliabilitas}

Salah satu syarat penting properti psikometris yang baik adalah memiliki validitas dan reliabilitas yang baik. Alat ukur dikatakan reliable apabila skala memberikan konsistensi atau keakuratan terhadap hasil pengukuran. Reliabilitas juga mengacu pada seberapa jauh skala tersebut dapat dipercaya untuk mengukur konstruk yang diukur.

Tabel 4.

Reliabilitas

\begin{tabular}{lccc}
\hline & Cronbach's $\boldsymbol{\alpha}$ & Gutmann's $\boldsymbol{\lambda 6}$ & McDonald's $\boldsymbol{\omega}$ \\
\hline Koefisien & 0.814 & 0.862 & 0.835 \\
$\mathbf{N}$ & 337 & 337 & 337 \\
\hline
\end{tabular}

Berdasarkan hasil uji reliabilitas dengan teknik analisis reliabilitas Cronbach's $\alpha$, gutmann's $\lambda$, McDonald $\omega$, masing-masing menunjukkan koefisien reliabilitas sebesar $0.814,0.862$, dan 0.835 dengan reliabilitas tertinggi menggunakan metode Gutmann's $\lambda$. Secara umum, reliabilitas yang baik jika memiliki koefisien minimal 0.900 (Azwar, 2017). Namun dalam beberapa hal, seperti yang diungkapkan De Vaus (Anggoro \& Widhiarso, 2010) bahwa reliabilitas memiliki nilai yang memuaskan dengan koefisien 0.70. Sehingga dapat dikatakan dengan koefisien sebesar 0.862 menunjukkan jika skala karakter nasionalismemiliki tingkat kepercayaan yang tinggi.

\section{Norma dan Interpretasi}

Untuk merubah nilai atau skor hasil respon subjek (kuantitatif) sehingga memiliki makna tertentu (kualitatif) maka diperlukan adanya sistem penormaan yang didasari atas skor populasi teoritis sehingga 
Jurnal Psikologi Terapan dan Pendidikan

ISSN: $2715-2456$

Vol. 1, No. 2, November 2019, pp. 63-98

dapat di interpretasi berdasarkan kelompok populasi. Dengan adanya norma maka peneliti atau pengguna skala akan dapat memaknai respon subjek terhadap hasil pengukuran (Azwar, 2017). Norma dalam penelitian ini menggunakan norma hipotetik untuk menginterpretasi skor alat ukur keseluruhan maupun norma interpretasi komponen.

\section{Norma Alat Ukur Karakter Nasionalisme}

Karakter nasionalisme dalam skala ini didefinisikan sebagai suatu perilaku pada siswa yang senantiasa menjunjung tinggi rasa cinta dan bangga terhadap bangsa dan tanah air yang teraktualisasikan melalui sikap dan tindakan yang mencerminkan kesetiaan, ketaatan, kepedulian, serta penghargaan yang tinggi terhadap NKRI termasuk kesukarelaan untuk mementingkan kepentingan bangsa dan negara diatas kepentingan pribadi dan kelompok demi tercapainya kehidupan berbangsa dan bernegara yang adil, makmur, dan sejahtera.

Menjunjung tinggi rasa cinta dan kebanggan terhadap bangsa dan tanah air mengindikasikan aspek kecintaan individu pada tanah airnya yaitu Indonesia. Kecintaan terhadap bangsa dan tanah air menunjukkan jika individu memiliki wawasan dan pengetahuan mengenai bangsa dan tanah airnya sehingga tumbuhlah rasa kebanggaan menjadi bagian yang terintegrasi dari kelompok bangsa. Kesetiaan dalam pengertian tersebut merujuk pada pengabdian individu terhadap negaranya dengan turut serta berperan aktif untuk menjaga kesatuan dan persatuan bangsa serta mengupayakan kemajuan dan kemakmuran bagi bangsa dan negara. Ini dapat dilakukan dengan berusaha menjadi pribadi yang berkarakter unggul dan berprestasi dalam berbagai bidang kehidupan. Ketaatan dalam pengertian karakter nasionalis mencirikan kepatuhan individu terhadap hukum dan peraturan yang berlaku. Penghargaan tinggi terhadap NKRI merujuk pada beberapa makna dimana aspek ini mencerminkan tindakan individu untuk menghargai keragaman budaya yang ada diantara bangsa yang plural serta kemampuan individu untuk mengapresiasi kekayaan budaya bangsa yang lahir dari sistem kebudayaan bangsa seperti bahasa, lingkungan fisik, keadaan sosial, budaya, ekonomi, juga politik. Sedangkan kesukarelaan untuk mementingkan kepentingan bangsa dan negara diatas kepentingan pribadi dan kelompok berarti kebersediaan dan keiklasan individu untuk melakukan sesuatu demi kebaikan dan keutuhan bangsa negaranya tanpa mengharapkan keuntungan apapun bahkan sekalipun jika pengorbanan yang ia lakukan memberikan rasa ketidaknyamanan ataupun kerugian bagi diri pribadinya. 
Jurnal Psikologi Terapan dan Pendidikan

ISSN: $2715-2456$

Vol. 1, No. 2, November 2019, pp. 63-98

Pengertian tersebut didasarkan pada observed variables yang membentuk komponen-komponen karakter nasionalis siswa SMA. Berdasarkan hasil analisis komponen terhadap observed variables didapatkan 5 komponen yang menyusun karakter nasionalisme pada siswa SMA yaitu komponen cinta tanah air, menghormati keragaman budaya, apresiasi budaya, taat hukum serta unggul dan berprestasi. Karakter nasionalis memiliki koefisien muatan faktor yang tinggi secara berturut-turut pada komponen taat hukum, menghargai keragaman budaya, apresiasi budaya, cinta tanah air serta terakhir unggul dan berprestasi. Berdasarkan komponen penyusunnya dapat dipahami jika karakter nasionalisme memiliki tiga implikasi makna yang terkandung didalamnya yaitu: adanya kesadaran dan kepatuhan warga negara terhadap hukum yang berlaku; penghargaan dan penghormatan terhadap keanekaragaman budaya yang ada di negaranya; serta senantiasa berusaha menjadi pribadi yang unggul dan berprestasi.

Adanya kesadaran dan kepatuhan warga negara terhadap hukum yang berlaku dikarenakan Indonesia merupakan negara merdeka dan berdaulat yang berasaskan pada hukum. Penghargaan dan penghormatan terhadap keanekaragaman budaya yang ada di negaranya dikarenakan Indonesia adalah negara plural yang memiliki banyak kebudayaan yang tersebar diseluruh wilayah daerah geografisnya. Kebudayaan tersebut merupakan hasil dari sejarah panjang Indonesia sebelum masa kemerdekaan (nusantara), yaitu Indonesia pada masa kerajaan-kerajaan. Dimana berbagai kebudayaan masuk ke nusantara melalui perdagangan diberbagai daerah wilayah nusantara yang menyebabkan berbagai kebudayaan yang datang dan telah ada saling beralkuturasi dan berasimilasi menghasilkan berbagai macam kebudayaan dan menjadikan Indonesia kini kaya akan kebudayaan sebagai bentuk warisan leluhur bangsa. Disisi lain senantiasa berusaha menjadi pribadi yang unggul dan berprestasi merupakan salah satu bentuk karakter yang harus dimiliki oleh bangsa Indonesia saat ini. Karakter tersebut merupakan bentuk perjuangan bangsa Indonesia kini dalam mengembangkan, memajukan, mengharumkan, dan mensejahterakan bangsa dan negaranya. Kemajuan dan kesejahteraan negara hanya akan dapat tercapai ketika bangsa Indonesia memiliki karakter unggul dan berorientasi prestasi. Ini karena karakter tersebut akan menjadi individu menjadi pribadi yang kompetitif, memiliki tekad, dan tujuan sehingga senantiasa berusaha untuk bergerak maju (progresif) dalam mencapai tujuannya yang mana ini akan berimplikasi pada kemajuan dan kesejahteraan bangsa dan negara Indonesia sendiri.

Secara psikologis nasionalisme ini mengindikasikan sebuah identitas sosial yang mengidentifikasikan seseorang pada suatu kelompok. Bagi bangsa Indonesia pengidentifikasian diri terhadap kelompok yang satu (homogen) dikarenakan adanya keterhubungan secara psikologis yang dirasakan oleh setiap anggota kelompok yaitu adanya perasaan senasib dan sepenanggungan - yang menumbuhkan perasaan untuk bersatu menjadi suatu kelompok bangsa. Pada tahapan tersebut individu 
Jurnal Psikologi Terapan dan Pendidikan

ISSN: $2715-2456$

Vol. 1, No. 2, November 2019, pp. 63-98

dari berbagai etnis yang berbeda mengidentifikasikan dan mengasosiasikan perasaan mereka ketika mereka berusaha menjadi bagian dari kelompok nasional. Berbagai karakteristik anggota komunitas bangsa yang berasal dari berbagai etnis saling berinteraksi dengan konsepsi identitas naisonal untuk membentuk, sikap, perilaku, dan penilaian mengenai anggota kelompok mayoritas (Yogesswaran \& Dasgupta, 2014).

Menurut Kusumawardani dan Faturochman (2004) bersatunya setiap kelompok masyarakat menjadi satu komunitas bangsa memiliki konsekuensi yang harus ditanggung oleh para anggota kelompok tersebut dimana salah satunya adalah mempertahankan keutuhan kelompok dari ancaman yang dari luar. Lebih lanjut dijelaskan oleh Kusumawardani dan Faturochman bahwa nasionalisme yang lahir dari suatu bangsa menuntut adanya perwujudan nilai-nilai dasar yang berorientasi pada kepentingan bersama dan menghindarkan segala legalisasi kepentingan pribadi atau kelompok yang dampak merusak tatanan kehidupan bersama. Inilah arti penting hukum yang menyatukan dan mengikatan warga negara sehingga memiliki satu identitas nasional.

Sebagai negara yang berdaulat dan berasas hukum maka sudah jelas nasionalisme pada individu dimaknai sebagai kepatuhan terhadap hukum yang berlaku Ini seperti yang dijelaskan oleh Josephson (2002) yang memaknai ketaatan hukum sebagai nilai kebajikan kewarganegaraan. Dimana menurut Josephson kewarganegaraan mencakup kebajikan sipil dan tugas-tugas yang menentukan bagaimana seorang individu seharusnya berperilaku sebagai bagian dari komunitas. Warga negara yang baik sudah semestinya mengetahui hukum dan mentaatinya. Individu berusaha untuk memberikan lebih dari sekedar memberi "cukup" untuk masyarakat, bangsa, dan negara. Ini dikarenakan warga negara yang baik ia akan berusaha memberi lebih dari apa yang ia terima.

Disisi lain ketaatan terhadap hukum yang berlaku ini bertujuan untuk menyamakan seluruh warga negara yang berasal dari latar belakang budaya berbeda teridentifikasi dalam satu identitas nasional serta untuk memberikan kedudukan yang sama dimata hukum. Sementara itu disaat individu yang nasionalis mengidentifikasikan dirinya sebagai satu identitas yaitu bangsa Indonesia, disisi lain mereka tetap harus menjunjung tinggi dan mengapresiasi kekayaan budaya yang ada pada bangsanya serta berupaya untuk melestarikannya. Ini mengindikasikan bahwa individu yang nasionalis menerima segala bentuk keragaman yang ada diantara sesamanya serta berupaya untuk mengapresiasi produk kekayaan budaya sebagai hasil dari sistem kebudayaan leluhur bangsa.

Disamping itu karakter nasionalis juga mengindikasikan individu yang senantiasa berusaha menjadi pribadi yang unggul dan berprestasi. Senantiasa berusaha menjadi pribadi yang unggul dan berprestasi bukan berarti mengharuskan setiap warga negara menjadi yang nomor satu dan terbaik dalam 
Jurnal Psikologi Terapan dan Pendidikan

ISSN: $2715-2456$

Vol. 1, No. 2, November 2019, pp. 63-98

berbagai bidang, melainkan ini bermakna suatu usaha bahwa setiap individu senantiasa berorientasi pada keunggulan dan prestasi. Bangsa yang berorientasi pada keunggulan dan prestasi ia akan selalu berusaha melakukan yang terbaik pada apapun yang ia lakukan dan kerjakan. Ia akan mengerjakan segala sesuatu dengan sungguh-sungguh dan berusaha mengerahkan kemampuannya semaksimal mungkin yang ia bisa. Individu yang memiliki karakter nasionalis memiliki semangat yang baik untuk mengerjakan segala sesuatu dengan kemampuannya sendiri - yang mana ini berarti ia jujur dan tidak berlaku curang untuk mendapatkan apa yang ia mau dan inginkan. Individu yang unggul dan berprestasi akan menjauhkan dirinya dari hal-hal yang buruk. Setiap bangsa wajib memiliki semangat untuk menjadi pribadi yang unggul dan berprestasi - dengan memiliki semangat ini maka individu telah memberikan kontribusi yang besar untuk memajukan, membesarkan, dan mengharumkan nama bangsa Indonesia. Maka dari itu sebagai siswa yang berkarakter nasionalis senantiasa berusaha belajar dan berlatih dengan sungguhsungguh pada bidang yang ia tekuni saat ini merupakan salah satu cara untuk menjadi warga negara yang baik agar kelak dapat berkontribusi dalam pembangunan dan kemajuan untuk bangsa dan negara yang sejahtera.

Tabel 5 ini adalah tabel kategorisasi norma hipotetik alat ukur karakter nasionalis secara keseluruhan yang mengklasifikasikan respon subjek terhadap aitem. Terbagi menjadi lima jenjang kontinum nilai yaitu; sangat tidak nasionalis, tidak nasionalis, cukup nasionalis, nasionalis, sangat nasionalis.

Tabel 5.

Norma Hipotetik Alat Ukur Karakter Nasionalisme

\begin{tabular}{ll}
\hline \multicolumn{1}{c}{ Klasifikasi } & \multicolumn{1}{c}{ Skor } \\
\hline Sangat nasionalis & $\geq 88$ \\
Nasionalis & $\geq 75-87$ \\
Cukup nasionalis & $\geq 50-74$ \\
Tidak nasionalis & $\geq 38-49$ \\
Sangat tidak nasionalis & $<38$ \\
\hline
\end{tabular}

\section{Norma Skala per Komponen}

Untuk dapat mengelompokan dan menjelaskan bagaimana dinamika karakter nasionalisme pada diri individu, maka peneliti membuat kategorisasi norma berdasarkan komponen yang membentuk konstruk skala karakter nasionalisme. Sehingga dapat diketahui dengan jelas dinamika karakter nasionalis pada diri individu pengguna alat ukur skala karakter ini.

\section{Kategori Norma Hipotetik Komponen Cinta Tanah Air}

Komponen cinta tanah air dalam skala karakter nasionalisme ini didefinisikan sebagai kerelaan untuk melayani, menjaga, memelihara, mempertahankan maupun melindungi keutuhan NKRI dengan seluruh keragaman dan kekayaan yang ada didalamnya dari segala gangguan maupun ancaman yang 
Jurnal Psikologi Terapan dan Pendidikan

ISSN: $2715-2456$

Vol. 1, No. 2, November 2019, pp. 63-98

mengancam integritas bangsa dan Negaradengan senantiasa menghayati serta menjunjung kecintaan dan kebanggaan terhadapnya dalam setiap tindak tanduk yang dilakukan.

Menghayati dan menjunjung kecintaan dan kebanggan terhadap NKRI pada dasarnya melibatkan aspek kognitif, afektif, dan konatif. Hal itu karena untuk mencintai dan memiliki rasa bangga memerlukan wawasan mengenai bangsa dan negara terlebih dahulu sehingga menumbuhkan "perasaan memiliki" dan menjadi bagian kelompok bangsa -yang turut pula memunculkanrasa bangga terhadap NKRI sehingga karenanya selalu berusaha untuk memberikan dan menjadi yang terbaik untuk Indonesia, termasuk berusaha untuk mengapresiasi apa yang dimiliki oleh Negara dan karya bangsa Indonesia.

Komponen ini merupakan salah satu komponen penting dalam karakter nasionalisme. Ini ditunjukkan dengan nilai muatan faktor yang tinggi terhadap observed variables taat hukum yang menyusun komponen cinta tanah air. Komponen ini terbentuk dari aitem-aitem cinta tanah air, menjaga lingkungan, taat hukum, disiplin, serta rela berkorban. Komponen ini memiliki koefisien muatan faktor yang sangat baik pada aitem taat hukum dan cinta tanah air, koefisien muatan faktor yang baik pada aitem menjaga lingkungan dan disiplin, serta koefisien muatan faktor yang cukup pada aitem rela berkorban. Ini sekaligus menunjukkan jika taat hukum, cinta tanah air, menjaga lingkungan, dan disiplin sebagai observed variables mayor dan rela berkorban sebagai observed variables minor.

Berdasarkan observed variables penyusun serta definisi komponen cinta tanah air menjelaskan jika komponen cinta tanah air sebagai sikap dan tindakan yang menunjukkan adanya kebersediaan untuk melayani, menjaga, memelihara, mempertahankan dan melindungi keutuhan bangsa dan Negara. Definisi tersebut mengindikasikan beberapa hal sebagai aspek cinta tanah air yaitu melayani dan menjaga persatuan bangsa, memelihara dan mempertahankan lingkungan alam sekitar serta kekayaan tak benda yang dimiliki Indonesia lainnya, serta melindungi integritas dan martabat bangsa serta Negara didalam negeri sendiri maupun dihadapan bangsa dan Negara lain.

Melayani dan menjaga persatuan bangsa berkaitan dengan hubungan interpersonal individu sebagai kelompok bangsa. Ini bermakna bahwa individu yang cinta tanah air senantiasa mencintai, mengasihi, serta peduli dengan bangsa dan negaranya. Ia selalu berusaha menjaga kerukunan dan keharmonisan didalam masyarakat yang plural. Mereka menerima perbedaan yang ada diantaranya dan tidak membeda-bedakan atau mengkotakkan orang berdasarkan asal atau status tertentu.Ini merujuk pada perbedaan suku, budaya, agama, bahasa, status sosial, ekonomi, perbedaan politik, bahkan perbedaan pendapat sekalipun - tidak akan membuat individu membeda-bedakan dirinya dengan orang lain. Ia akan memperlakukan semua orang dengan adil, tidak memperlakukan orang dengan semena-mena hanya karena perbedaan itu. 
Jurnal Psikologi Terapan dan Pendidikan

ISSN: $2715-2456$

Vol. 1, No. 2, November 2019, pp. 63-98

Hal tersebut dikarenakan Indonesia dan pluralitas merupakan satu kesatuan yang tidak dapat dipisahkan. Sebagai Negara yang lahir dari banyaknya kerajaan yang tersebar dari Sabang sampai Merauke dengan berbagai perbedaan karakteristik geografisnya yang melahirkan perbedaan-perbedaan budaya, tradisi, bahasa, keyakinan, gaya hidup, mata pencaharian, sistem perekonomian, sistem kemasyarakatan, dan lain sebagainya -menyebabkan Indonesia kaya akan keberagaman (pluralitas). Perbedaan tersebut sejatinya bukanlah hal yang menjauhkan atau memisahkan antar kelompok etnis bangsa di Indonesia. Adanya pengalaman terjajah dan perjuangan memperebutkankemerdekaan menyatukan seluruh entitas budaya yang berbeda sehingga menjadi satu kelompok bangsa Indonesia tanpa embel-embel asal daerah lagi yang melekat pada diri individu ataupun kelompok.

Aspek persatuan masyarakat yang berasal dari berbagai elemen kelompok di Indonesia ini dapat dijelaskan secara teoritis seperti yang diterangkan oleh Yogesswaran dan Dasgupta (2014) bahwa terjadinya disintegrasi dua sistem budaya menciptakan pembukaan untuk membentuk komunitas baru dan mengatur babak baru bagi bangsa yang modern. Di Indonesia sistem kebudayaan yang berdisintegrasi ini merupakan hasil dari akulturasi dan asimilasi dari berbagai kebudaya daerah sehingga muncullah kebiasaan-kebiasaan tertentu di Negara Indonesia yang menjadi suatu kebudayaan nasional sehingga tidak ada lagi sekat yang memisahkan masyarakat dari suatu daerah tertentu dengan daerah lain.Ini memunculkan perasaan kebersamaan dan persaudaraan sekalipun mereka tidak saling mengenal satu sama lain sebagai suatu bentuk persatuan bangsa.

Kebudayaan nasional memberikan kesamaan pada segenap warga Negara yaitu adanya identitas nasional seperti yang tertuang dalam sumpah pemuda. Identitas nasional tersebut yaitu mengakui asalusulnya adalah tanah air yang merujuk pada Negara Indonesia terlepas dimanapun ia dilahirkan dan dibesarkan. Individu warga negara Indonesia menganggap bahwa Indonesia adalah 'rumah' dan tanah kelahirannya, sehingga ia akan menjaga alam dan lingkungan Indonesia dimanapun ia berada. Ia juga berusaha mengharumkan nama Indonesia di mata internasional.

Selain itu kebudayaan nasional ini menjadikan bangsanya yang plural menjadi satu identitas bangsa, yaitu bangsa Indonesia. Ini bermakna bahwa individu yang cinta tanah air mengakui bangsanya yaitu bangsa Indonesia. Individu juga memiliki kebanggaan terhadap jati dirinya sebagai bangsa Indonesia. Ia dapat menerima keberagaman budaya yang ada di Indonesia menjunjungnya sebagai kekayaan budaya daerah namun tidak menjadikannya bersifat etnosentris. Ini juga mengindikasikan bahwa bangsa yang cinta tanah air tidak serta merta menerima dan meniru budaya asing dengan mudah atau bahkan lebih mencintai kebudayaan bangsa Negara lain dan lebih menjunjungnya, melainkan individu tahu bagaimana harus mengambil kebudayaan positif dari Negara lain untuk kepentingan 
Jurnal Psikologi Terapan dan Pendidikan

ISSN: $2715-2456$

Vol. 1, No. 2, November 2019, pp. 63-98

mengembangkan kualitas diri menjadi pribadi lebih baik. Ini seperti mencontoh budaya kerja di Jepang untuk mengembangkan karakter kerja keras dan visioner - namun tidak serta merta meniru keseluruhan karakter bangsa Jepang. Individu tetap menjaga jati dirinya sebagai bangsa Indonesia dan menjaga perilakunya sebagai bentuk menjaga nama baik bangsa Indonesia di mata Internasional.

Kemudian yang paling penting adalah masyarakat Indonesia menjunjung bahasa nasionalnya yaitu bahasa Indonesia. Menjunjung bahasa mengandung makna lebih dari mengakui, ini karena individu yang cinta tanah air akan berusaha memahami dan menggunakan bahasa tersebut dengan baik dan benar dalam berbagai kesempatan. Ini mengindikasikan kebanggaan individu dalam berbahasa Indonesia terlebih ketika berkomunikasi saat ia berada di negaranya sendiri - Indonesia. Individu senang berkomunikasi dengan bahasa Indonesia dan berusaha mempelajarinya dengan baik. Ia tidak akan melecehkan bahasa Indonesia dengan menggunakannya bersamaan dengan bahasa asing atau merubah bahasanya.

Persatuan yang terjadi pada masyarakat Indonesia yang plural bukanlah hal mudah, namun dengan kesamaan perasaan senasib dan seperjuangan dapat menyatukan seluruh individu dari berbagai elemen kelompok masyarakat. Ini seperti yang dijelaskan oleh Anderson (Yogesswaran \& Dasgupta, 2014) bahwa bangsa sebagai kelompok nasional yang cukup besar dengan anggota-anggota yang tidak akan pernah mengenal semua anggota satu sama lain, namun setiap anggota bangsa akan mengidentifikasikan diri mereka dengan bangsanya dan merasakan hubungan dengan anggota-anggota lain didalam Negara. Perasaan yang menyatukan bangsa ini dalam psikologi menurut Anderson (Yogesswaran \& Dasgupta, 2014) dikarenakan anggota-anggotanya terhubung secara psikologis karena merasakan nasib yang sama dengan mereka. Adanya perasaan ini mengikat kelompok masyarakat yang plural hingga menjadi suatu kelompok homogen dengan kecintaan tanah air yang meleburkan segala perbedaan. Lebih dari itu, adanya 'perasaan senasib seperjuangan' yang lahir dari persatuan dan adanya rasa cinta tanah air menjadikan bangsanya memiliki karakter ramah tamah dan rendah hati terhadap siapapun tanpa melihat lagi ciri atau karakteristik tertentu yang membedakan antar kelompok bangsa (etnis). Sifat ini telah menjadi identitas nasional bagi bangsa Indonesia yang telah dikenal bahkan oleh bangsa asing.

Disisi lain aspek cinta tanah air ini juga mengindikasikan adanya sikap dan tindakan menjaga, memelihara dan mempertahankan lingkungan alam sekitar maupun kekayaan tak benda milik Indonesia lainnya termasuk karya anak bangsa Indonesia. Ini mengindikasikan sikap dan tindakan individu yang bersedia menjaga alam dan lingkungan sekitarnya juga menjaga dan melestarikan kekayaan-kekayaan kebudayaan daerah di Indonesian maupun karya anak bangsa dari klaim atau pengakuan bangsa lain. 
Jurnal Psikologi Terapan dan Pendidikan

ISSN: $2715-2456$

Vol. 1, No. 2, November 2019, pp. 63-98

Menjaga dan memelihara alam dan lingkungan mengandung makna kesediaan individu dalam menjaga kebersihan serta keasrian alam dan lingkungan sekitar, tidak merusak infrastruktur masyarakat, termasuk juga melestarikan dan mempromosikan dan mempopulerkan wisata alam Indonesia agar wisata Indonesia lebih banyak dikenal oleh masyarakat Indonesia dan lebih memilih untuk berwisata dinegerinya sendiri juga agar lebih dikenali oleh bangsa asing agar berwisata di Indonesia. Individu tidak membiarkan kelompok tertentu memprovokasi masyarakat lainnya bahkan memecahkan persatuan yang berdampak pada lepasnya wilayah tersebut dari NKRI. Ini bertujuan untuk menjaga keamanan dan keharmonisan disetiap wilayah di Indonesia dan mewujudkan tempat tinggal yang aman dan ramah bagi setia warganya dan warga dari daerah lain.

Selain itu memelihara dan mempertahankan kekayaan-kekayaan budaya daerah dan anak bangsa adalah tidak membiarkan bangsa asing mengakui atau mengklaim kekayaan kebudayaan daerah yang dimiliki Indonesia dan produk-produk atau karya anak bangsa. Ini dilakukan dengan tidak malu untuk menggunakan pakaian tradisional, memakan masakan daerah, melakukan pertunjukan tarian tradisional, mendengarkan musik daerah, dan lain sebagainya. Selain itu dengan kesadaran penuh dan kesediaan untuk memperkenalkan dan mempopulerkan kekayaan budaya tersebut kepada generasi penerus bangsa bahkan kepada dunia internasional misal dengan ikut berpartisipasi dalam festival budaya di luar negeri, ikut dalam perlombaan budaya di luar negeri, atau mengekspor produk kerajinan Indonesia ke luar negeri.

Kekayaan ini tidak berarti hanya berupa produk budaya tradisional, namun juga berarti karyakarya anak bangsa seperti produk-produk kerajinan tangan, mode fashion pakaian, sepatu, tas, dan aksesoris, pertunjukan hiburan seperti film dan musik ataupun yang lainnya. Ini mengandung makna kesediaan masyarakat Indonesia untuk lebih menggunakan dan mempopulerkan produk dalam negeri dibandingkan produk luar negeri. Ini dikarenakan menggunakan dan mempopulerkan produk dalam negeri juga berarti menyelematkan perekonomian Negara serta memakmurkan bangsa Indonesia sendiri. Disisi lain ini perilaku ini akan memacu masyarakat untuk lebih termotivasi untuk berkarya dan berinovasi sehingga menjadikan individunya lebih kompetitif dalam menghasilkan karya terbaik yang bermanfaat, dan dikenal oleh seluruh masyarakat Indonesia ataupun masyarakat luar negeri.

Terakhir, aspek cinta tanah air mengindikasikan adanya sikap dan tindakan melindungi integritas dan martabat bangsa serta Negara baik didalam negeri sendiri maupun dimata dunia internasional. Ini merujuk kepada bagaimana individu membawakan dirinya dalam berbangsa dan bernegara. Seseorang yang cinta terhadap tanah airnya ia akan berusaha menjadi pribadi dan bangsa yang bermartabat. Ini dikarenakan setiap tindak tanduk yang dilakukannya akan berpengaruh terhadap identitas kelompok yang melekat padanya misal orangtua, keluarga, kelompok, ataupun bangsanya. Ini karena Indonesia adalah 
Jurnal Psikologi Terapan dan Pendidikan

ISSN: $2715-2456$

Vol. 1, No. 2, November 2019, pp. 63-98

negara dengan budaya kolektif - apa yang dilakukan oleh individu maka akan mencerminkan atau disangkut-pautkan dengan kelompoknya. Perilaku yang melindungi integritas dan martabat bangsa negara ini ditandai dengan individu yang taat hukum dan disiplin. Individu yang disiplin ia akan bersedia untuk mematuhi peraturan atau kesepakatan yang lahir dari suatu institusi, kesepakatan bersama, ataupun yang lahir karena adanya komitmen yang dibuat oleh diri sendiri. Ini merujuk pada pribadi yang teratur dan taat sehingga ia akan melaksanakan suatu komitmen, tugas, ataupun tanggung jawab tanpa paksaan apapun melainkan dengan penuh kesadaran dan kesukarelaan. Disisi lain pribadi yang disiplin juga menandakan individu yang mampu mengendalikan diri dari berbagai godaan yang berpotensi menghalanginya melaksanakankomitmen, tugas, atau kewajiban.

Disiplin tidak akan lepas dari tindakan taat terhadap hukum. Disiplin merupakan suatu tindakan implisit dari perilaku taat hukum. Aitem taat hukum memiliki koefisien korelasi tertinggi sebagai penyusun komponen cinta tanah air. Ini menandakan jika individu yang cinta terhadap tanah air maka ia akan bersedia untuk mematuhi dan taat terhadap hukum dan peraturan yang berlaku di Indonesia. Ini bukanlah tanpa sebab, sebagai sebuah Negara yang berdaulat, berasas hukum dan demokrasi - jelas Indonesia memiliki peraturan-peraturan perundangan yang mengikat dan mengatur seluruh warga negaranya dan menjadi polisi negara dalam menjalankan fungsinya. Ini berarti taat hukum bergerak dalam lingkup kewajiban individu menjalankan perannya sebagai warga Negara juga bagaimana Negara menjalankan kewajibannya terhadap warga negaranya. Maka dari itu individu baik sebagai masyarakat sipil maupun aparatur Negara yang menjalankan peran dan wakil kenegaraan wajiblah taat terhadap hukum yang berlaku. Ketaatan individu terhadap hukum dan peraturan yang berlaku menandakan individu yang bermartabat, sehingga pribadi yang taat terhadap hukum dan peraturan maka ia telah menjaga nama baik bangsa dan negaranya. Dengan ketaatan masyarakat sipil dan aparatur Negara terhadap hukum dan peraturan yang berlaku maka dapat menjamin dan menjadikan negara yang aman, damai, dan sejahtera bagi masyarakatnya.

Pada dasarnya sikap dan tindakan yang mencintai tanah air tidak dapat dipisahkan dari unsur kerelaan untuk berkorban. Ini karena rela berkorban merupakan unsur yang mencerminkan keiklasan individu untuk melakukan sesuatu tanpa mengharapkan sesuatu untuk kepentingannya sendiri, melainkan hanya untuk kepentingan bersama - bahkan bagi seseorang yang memiliki rasa cinta tanah air yang tinggi ia bersedia melakukan sesuatu bahkan jika itu menimbulkan rasa ketidaknyamanan dan kerugian bagi individunya. Ini merupakan aktualisasi tertinggi dari orang yang memiliki rasa cinta tanah air dalam dirinya yaitu adanya kesedian untuk berkorban demi kepentingan Negara dan bangsa. Disisi lain mendahulukan kepentingan Negara dan bangsa diatas kepentingan pribadi merupakan kewajiban yang 
Jurnal Psikologi Terapan dan Pendidikan

ISSN: $2715-2456$

Vol. 1, No. 2, November 2019, pp. 63-98

telah diatur secara tersirat dalam peraturan kenegaraan, namun orang yang memiliki rasa cinta tanah air yang tinggi tidak melakukan sesuatu karena keterpaksaan namun dengan kesadaran diri melakukan sesuatu untuk kebaikan bangsa dan Negara. Inilah mengapa unsur rela berkorban menjadi observed variables yang melandasi aspek cinta tanah air, karena unsur kebersediaan atau kerelaan melakukan sesuatu merupakan tindakan aktual yang memiliki nilai tinggi dalam aspek cinta tanah air.

Komponen cinta tanah air yang menyusun karakter nasionalis dalam skala ini memiliki standar penilaian dan interpretasi yang dapat dijelaskan dalam tabel 6 dibawah ini.

Tabel 6.

Norma Hipotetik Komponen Cinta Tanah Air

\begin{tabular}{ll}
\hline \multicolumn{1}{c}{ Klasifikasi } & \multicolumn{1}{c}{ Skor } \\
\hline Sangat cinta terhadap tanah air & $\geq 35$ \\
Cinta terhadap tanah air & $\geq 29-34$ \\
Cukup cinta terhadap tanah air & $\geq 15-28$ \\
Tidak cinta terhadap tanah air & $\geq 9-14$ \\
Sangat tidak cinta terhadap tanah air & $<8$ \\
\hline
\end{tabular}

\section{Kategori Norma Hipotetik Komponen Menghargai Keragaman Budaya}

Komponen menghargai keragaman dalam karakter nasionalis ini didefinisikan sebagai perilaku yang menunjukkan sikap dan tindakan yang mencerminkan kemampuan siswa untuk menghormati, mengakui danmenerima perbedaan dan keberagaman budaya, suku, ras, dan agama yang melekat pada diri orang-orang disekitar dengan berusaha untuk berperilaku sama adil dan juga bertanggung jawab tanpa membedakan atau mengkotakkan perbedaan yang ada ataupun mengunggulkan kelompoknya sendiri dan merendahkan kelompok lain. Pengertian ini dimaksudkan agar berbagai macam perbedaan yang melekat pada diri individu tidaklah dianggap sebagai "perbedaan" yang membatasi interaksi dan mengkelompokkan diri pada kelompok yang sesuai dengan kesamaan ciri tertentu - namun sebaliknya justru menganggap perbedaan karakteristik tersebut sebagai sebuah bentuk keragaman yang berarti keindahan dalam interaksi sosial dan tetap dapat menerima perbedaan tersebut dengan sikap saling peduli, mendukung, dan bekerjasama agar dapat dicapai kepuasan dalam interaksi sosial.

Ini tidak terlepas karena Indonesia dan pluralitas adalah dua hal yang tidak dapat dipisahkan. Pluralitas di Indonesia merupakan bentuk identitas nasional Indonesia. Letak geografis setiap wilayah yang berbeda dan perbedaan sejarah disetiap daerah memperkaya keberagaman budaya, suku, dan agama pada masyarakatnya. Setiap daerah ataupun budaya akan memiliki perbedaan bahasa, nilai, cara dan prinsip hidup, kepercayaan, pendapat, dan keyakinan yang turut pula akan berbeda karena beragam budaya, suku, dan agama yang kesemuanya merupakan hasil dari sistem budaya yang 
Jurnal Psikologi Terapan dan Pendidikan

ISSN: $2715-2456$

Vol. 1, No. 2, November 2019, pp. 63-98

melatarbelakanginya. Oleh karena itu wajar jika perbedaan dipandang sebagai bentuk keberagaman yang indah, sehingga setiap individu haruslah dapat menerima dan menghormati keberagaman yang ada pada diri orang lain dan tidak bersikap sentimen ataupun bermusuhan terhadap individu atau kelompok tertentu.

Komponen ini merupakan komponen paling utama yang mengindikasikan karakter nasionalis. Ini ditunjukkan dengan nilai koefisien muatan faktor yang paling tinggi diantara observed variables yang menyusun komponen lain dalam karakter nasionalis. Aitem menghagai perbedaan agama, ras, budaya bangsa memiliki nilai koefisien muatan faktor yang sangat baik dan baik begitu juga dengan aitem unggul dan berprestasi yang memiliki koefisien muatan komponen yang sangat baik sebagai observed variables yang menyusun komponen menghargai keragaman budaya bangsa. Ini menandakan seseorang yang berkarakter ia memiliki perilaku mampu menghargai keragaman yang ada pada individu disekitarnya dan dengan begitu maka individu telah menunjukkan kualitas diri yang unggul yang ada pada dirinya.

Hal itu dikarenakan toleransi terhadap keberagaman yang ada disekitar bukanlah hal yang mudah. Nilai, kepercayaan, keyakinan, pandangan, atau pendapat adalah sesuatu yang dibentuk berdasarkan sistem kebudayaan yang terdapat dan melingkupi diri seorang individu. Bersikap terbuka dan menerima perbedaan tersebut sebagai suatu keragaman yang mewarnai individu-individu pada kelompok heterogen terkadang sulit untuk dicapai. Ini karena individu terkadang membawa dan merasa lebih unggul pada apa yang diyakininya dan menilai bahwa nilai-nilai budaya lain adalah sesuatu yang salah dan bertentangan dengan nilai yang ia yakini.

Individu yang mampu berperilaku menghargai keragaman ia adalah pribadi yang mampu mengaktualisasikan dirinya dengan menjadi pribadi yang mampu menerima perbedaan, serta kebersediaan untuk berperilaku sama peduli dan saling tolong menolong sehingga mencerminkan pribadi yang berperilaku sosial yang bertanggung jawab.Dengan menjadi pribadi yang bertanggung jawab secara sosial maka individu telah berupaya untuk menghargai harga diri dan hak asasi setiap orang. Ini adalah bentuk penghargaan tertinggi dari keberagaman tersebut dengan tidak lagi menjadikan perbedaan sebagai penghalang komunikasi dan kepedulian antarsesama namun sebagai sesuatu keberagaman yang sejatinya justru saling melengkapi, melindungi dan untuk mencapai kebaikan, keselarasan, dan keseimbangan dalam kehidupan berbangsa dan bernegara yang heterogen.

Maka dari itu individu yang mampu menghargai keragaman budaya berarti ia telah menunjukan keunggulan dalam dirinya. Individu yang berorientasi pada prestasi ia senantiasa akan belajar dengan gigih dan kerja keras serta mampu bekerjasama dengan siapa saja tanpa dihalangi dan dibatasi oleh perbedaan-perbedaan yang ada pada dirinya dan orang lain. Ini adalah kualitas keunggulan seorang individu yang mampu menciptakan interaksi yang harmonis dan memuaskan dengan individu lain. Ini 
Jurnal Psikologi Terapan dan Pendidikan

ISSN: $2715-2456$

Vol. 1, No. 2, November 2019, pp. 63-98

dikarenakan individu yang mampu menghargai keragamanadalah individu yang cerdas kompetensi sosial yang baik.

Dengan merujuk pada hasil analisis observed variables karakter nasionalis maka kemampuan dan perilaku menghargai keragaman adalah salah satu hal utama yang mengindikasikan karakter nasionalis individu. Ini bukanlah tanpa sebab, selain Indonesia merupakan negara berdaulat yang memiliki hukum dan peraturan yang menyelaraskan semua kelompok bangsa sebagai satu kelompok yang memiliki satu identitas nasional - namun disisi lain Indonesia tidak dapat dilepaskan dari karakteristik keberagaman budaya, ras, ataupun suku yang melatar belakangi individu. Indonesia adalah negara yang menjunjung harga diri dan hak asasi seluruh bangsanya. Maka dari itu, selain dengan menyelaraskan seluruh kelompok masyarakat menjadi satu indentitas nasional - masyarakat Indonesia tetap harus menjunjung budaya daerahnya masing-masing. Ini dikarenakan budaya juga turut berperan dalam pembentukan perilaku setiap individunya. Budaya dapat menjadi perantara untuk membentuk karakter atau suatu kebajikan tertentu melalui metode pengajaran individu berbasiskan pendekatan budaya (pendidikan multikultura). Ini seperti yang dijelaskan oleh Fisher (Agustian, Anindyta, \& Grace, 2018) budaya dapat menentukan cara seseorang bertindak, menentukan perilaku individu dalam berhubungan dengan individu lain (menentukan interaksi sosial individu atau kelompok budaya), dan menentukan cara berpikir dan memahami sesuatu disekitarnya.

Pada siswa SMA kemampuan atau perilaku menghargai keragaman ini dapat dilakukan dengan bersikap menerima perbedaan yang ada pada dirinya dan orang lain, memperlakukan orang sama adil, peduli, dan bersedia untuk berteman dengan siapa saja tanpa dibatasi oleh perbedaan kebudayaan, agama ataupun ras, serta berusaha untuk saling bekerjasama dan melindungi satu sama lain.

Disisi lain berdasarkan perspektif psikologis - kemampuan ini merupakan suatu tugas perkembangan tersendiri yang harus dipenuhi oleh individi remaja seperti siswa SMA. Ini dikarenakan tugas perkembangan seorang remaja adalah untuk mencapai hubungan baru yang lebih matang dan berperilaku sosial yang bertanggung jawab (Hurlock, 2014). Kemampuan untuk berperilaku sosial yang bertanggung jawab pada masa remaja ini terjadi seiring meluasnya kesempatan melakukan kontak sosial. Dengan banyaknya kontak sosial yang dilakukan seharusnya turut menambah wawasan dan kompetensi sosial remaja pula yang semakin membaik. Remaja semakin mampu untuk menilai dan menerima temantemannya dengan lebih baik karena kemampuan penyesuaian diri dalam situasi sosial yang semakin baik pula sehingga mampu menghindari berbagai macam konflik dan permusuhan terlebih diakibat adanya perbedaan. 
Jurnal Psikologi Terapan dan Pendidikan

ISSN: $2715-2456$

Vol. 1, No. 2, November 2019, pp. 63-98

Menerima dan menghargai keberagaman budaya merupakan salah satu bentuk kompetensi sosial yang harus dikuasai oleh remaja terutama yang tinggal pada wilayah yang heterogen atau plural. Ini merupakan suatu bentuk kemampuan sosial untuk dapat menciptakan kerukunan dan keharmonisan antar sesama anggota komunitas. Santrock (2009) turut memberikan penjelasan yang mendukung pernyataan Hurlock sebelumnya bahwa semakin baiknya kemampuan sosial remaja dikarenakan remaja menemukan perubahan-perubahan dalam pengambilan perspektif, yang berarti suatu kemampuan untuk mempertimbangkan sudut pandang orang lain serta memahami pikiran dan perasaannya.

Santrock (2009) menjelaskan lebih lanjut bahwa adanya kemajuan dalam pengambilan perspektif menyebabkan remaja menjadi lebih peduli mengenai hal-hal yang dipikirkan oleh orang lain. Oleh karena itu kemampuan pengambilan perspektif ini pada remaja dapat meningkatkan pemahaman diri remaja, meningkatkan status kawan sebaya, dan kualitas persahabatan mereka. Ini dikarenakan dengan mampu mengambil perspektif orang lain berarti individu mampu memahami kebutuhan dan kebersamaan dengan orang lain sehingga mereka dapat melakukan kontak sosial tanpa dihalangi oleh sikap egosentrisme tertentu yang membatasi kontak sosial tersebut. Ini merupakan suatu kompetensi sosial yang harus dimiliki oleh remaja yang tinggal di wilayah plural dan heterogen untuk dapat menghargai perbedaan sebagai bentuk keberagaman. Disamping itu dengan memahami perilaku-perilaku dan nilai-nilai budaya bangsa lain, memungkinkan setiap individu dapat saling berinteraksi dengan lebih efektif dan membuat bumi atau Indonesia sekalipun menjadi tempat yang ramah dan aman untuk ditinggali oleh seluruh individu dari kelompok manapun.

Komponen menghargai keberagaman budaya yang menyusun karakter nasionalis dalam skala ini memiliki standar penilaian dan interpretasi yang dapat dijelaskan dalam tabel 7 dibawah ini.

Tabel 7.

Norma Hipotetik Komponen Menghargai Keragaman Budaya

\begin{tabular}{lc}
\hline \multicolumn{1}{c}{ Klasifikasi } & Skor \\
\hline Sangat menghargai keragaman budaya & $\geq 12$ \\
bangsa & $\geq 10-11$ \\
Menghargai keragaman budaya bangsa & $\geq 6-9$ \\
Cukup dapat menghargai keragaman & $\geq 4-5$ \\
budaya bangsa & \\
Tidak dapat menghargai keragaman & $<4$ \\
budaya bangsa & \\
Sangat tidak dapat menghargai & \\
keragaman budaya bangsa &
\end{tabular}

\section{Kategori Norma Hipotetik Komponen Apresiasi Budaya Bangsa}


Jurnal Psikologi Terapan dan Pendidikan

ISSN: $2715-2456$

Vol. 1, No. 2, November 2019, pp. 63-98

Komponen apresiasi budaya bangsa adalah suatu perilaku pada siswa yang mampu menikmati, menghayati dan memberikan penilaian terhadap suatu produk budaya bangsa sehingga karenanya menumbuh kembangkan sikap dan tindakan yang menghargai produk kekayaan budaya tersebut dengan menjaga dan melestarikannya. Jika komponen menghargai keragaman budaya bangsa sebagai bentuk penghargaan dan penghormatan atas perbedaan dan keunikan individual dalam konsteks sosial maka apresiasi budaya bangsa merupakan komponen yang berusaha memberikan penghargaan dan penghormatan terhadap produk-produk kekayaan budaya bangsa dengan berusaha menjaga dan melestarikannya.

Komponen ini merupakan komponen utama yang memiliki keoefisien muatan faktor tertinggi membentuk komponen laten yang menyusun karakter nasionalis pada siswa SMA. Komponen apresiasi budaya melengkapi komponen menghargai keragaman budaya bangsa. Hal tersebut sebagaimana karakteristik karakter nasionalis yaitu adanya penghargaan dan penghormatan terhadap keanekaragaman budaya yang ada di negaranya. Ini karena Indonesia adalah negara plural yang memiliki banyak kebudayaan bangsa yang tersebar diberbagai daerah dikarenakan adanya sejarah panjang nusantara (Indonesia sebelum menjadi negara merdeka dan masih zaman kerajaan) yang menghadirkan banyak kebudayaan-kebudayaan yang beralkuturasi dan berasimilasi menjadi kebudayaan di Indonesia hingga menjadi negara berdaulat seperti saat ini. Maka dari itu penghargaan dan penghormatan terhadap kebudayaan tersebut adalah hal mutlak bagi bangsa Indonesia sebagai penghormatan terhadap warisan leluhur bangsa yang mana penghargaan dan penghormatan tersebut juga memiliki implikasi bahwa individu harus mampu mengapresiasi keberagaman kebudayaan bangsa tersebut.

Komponen ini terdiri dari aitem apresiasi budaya bangsa sebagai observed variables dominan dengan koefisien muatan faktor yang sangat baik terhadap komponen laten, juga koefisien muatan faktor yang sangat baik pada aitem menjaga kekayaan budaya. Berdasarkan hasil analisis komponen terhadap observed variables yang diketahui maka aktualisasi komponen ini adalah sikap dan tindakan siswa yang mampu mengapresiasi dan menjaga kekayaan budaya bangsa.

Telah disebutkan sebelumnya bahwa Indonesia adalah negara dengan banyak kebudayaan yang memiliki sistem kebudayaan tersendiri sehingga menghasilkan kepercayaan, keyakinan, nilai, prinsip, suku, adat, bahasa, pakaian, makanan, kesenian serta hasil-hasil kebudayaan lainnya yang berbeda pula. Ada banyaknya kebudayaan yang terdapat di Indonesia menghasilkan produk-produk kekayaan budaya yang beraneka ragam pula - yang berbeda antara satu daerah dengan daerah lainnya. Sebagai negara yang lahir dari keberagaman budaya dan menghargai hak asasi manusia maka sudah semestinya produk-produk kekayaan budaya bangsa tersebut juga harus diapresiasi dan dilestarikan. Mengapresiasi dan melestarikan 
Jurnal Psikologi Terapan dan Pendidikan

ISSN: $2715-2456$

Vol. 1, No. 2, November 2019, pp. 63-98

budaya bangsa berarti telah menunjukkan sikap dan tindakan yang melindungi identitas nasional bangsa dan negara Indonesia.

Perilaku mengapresi budaya bangsa yang menyusun aspek nasionalis ini berarti suatu bentuk kemampuan masyarakat untuk dapat menikmati, memahami, menghayati, dan menilai segala macam bentuk kekayaan budaya yang ada pada kebudayaannya juga kebudayaan lain di Indonesia sebagai bentuk apresiasi terhadap warisan leluhur bangsa. Bentuk konkrit dari perilaku mengapreasi kekayaan budaya bangsa ini adalah kesediaan individu atau masyarakat untuk menjaga dan melestarikan kebudayaan bangsa tersebut. Ini dikarenakan untuk mampu menjaga dan melestarikan kekayaan budaya tersebut dibutuhkan tekad untuk mengenal, mempelajari, memahami, mempraktikkanjuga kepekaan dan keterbukaan terhadap nilai-nilai kekayaan kebudayaan tersebut sehingga karenanya akan tumbuh perasaan bangga terhadap kekayaan budaya yang dimiliki Indonesia dan memunculkan perasaan memiliki serta tanggung jawab untuk melestarikannya. Oleh karena itu perilaku menjaga dan melestarikan kekayaan kebudayaan bangsa merupakan bentuk aktualisasi tertinggi dari apresiasi budaya bangsa.

Terlebih dizaman yang semakin modern ini, dimana berbagai generasi penerus bangsa saat ini lebih tergiur dengan kebudayaan asing yang dirasa lebih mampu menumbuhkan kepercayaan diri dan status dirinya. Banyak dari penerus bangsa saat ini merasa malu terhadap kebudayaannya sendiri dan cenderung enggan untuk mengenal, mempraktikkan, dan menggunakan kekayaan budaya tersebut dalam kehidupan. Ini menjadikan generasi saat ini buta terhadap kekayaan budaya bangsa yang mana ini mengindikasikan pula lunturnya semangat nasionalis penerus bangsa. Hal tersebutlah yang menjadi tantangan bagi generasi muda penerus bangsa saat ini yaitu untuk menumbuhkan kecintaan terhadap kekayaan budaya bangsanya sehingga memiliki semangat untuk menjaga kekayaan budaya bangsa itu sendiri.

Adanya cinta dan semangat untuk menjaga kekayaan budaya bangsa tersebut maka melestarikan bahkan memperkenalkannya ke dunia internasional bukan lah hal yang sulit. Bangsa lain akan mengenali kekayaan kebudayaan Indonesia apabila bangsa Indonesia sendiri selalu menggunakan dan melestarikannya. Ini juga akan mengindikasikan jati diri dan karakter yang kuat pada bangsa Indonesia yang mencintai kebudayaan bangsanya, sehingga bangsa asing pun tidak akan mampu melecehkan kebudayaan Indonesia atau bahkan mengakuinya sebagai kekayaan budaya bangsanya. Ini dikarenakan melestarikan budaya bangsa berarti turut pula menjaga keutuhan bangsa dan negara.

Siswa yang memiliki perilaku apresiasi kekayaan budaya bangsa dalam dirinya adalah pribadi yang cinta dan bangga terhadap kekayaan budaya yang ada di Indonesia. Ia bersedia menjaga dan melestarikannya dengan mempelajari, memahami, serta mempraktikkan dan mengajarkannya kembali 
Jurnal Psikologi Terapan dan Pendidikan

ISSN: $2715-2456$

Vol. 1, No. 2, November 2019, pp. 63-98

kepada orang lain agar lebih banyak orang yang mengenal dan memahami budaya Indonesia. Dalam contoh konkrit perilaku ini dapat diwujudkan dengan siswa mengikuti ekstrakulikuler dan mempelajari kesenian tradisional di sekolah atau diluar sekolah, bangga menggunakan produk kekayaan budaya bangsa, memperkenalkannya dengan memposting kesenian tersebut ke media sosialnya, ia juga bangga dan menikmati berbagai pertunjukan adat tradisi budaya bangsa sebagai bentuk keseimbangan antara kehidupan modern dengan warisan leluhur bangsa.

Pada remaja mengimplementasikan perilaku ini tampaknya menjadi sedikit berat untuk dilakukan. Ini dikarenakan secara psikologis remaja merupakan kelompok usia yang pada saat ini sedang berada pada masa eksplorasi diri dan berusaha mengidentifikasi diri terhadap model yang sesuai. Selain itu pada masa ini remaja juga merupakan bagian dari kelompok sebaya dimana akan mempengaruhi sikap, pembicaraan, minat, penampilan, dan perilaku yang mengikuti kelompok (Hurlock, 2014). Maka wajar pada masa ini jika remaja sangat mudah untuk mengikuti berbagai stereotip budaya popular yang sedang digandrungi disekitarnya. Hal tersebut dikarenakan dapat menambah nilai popularitas dan harga diri remaja tersebut. Sehingga apabila ia tidak memiliki stereotip budaya popular saat ini, mereka khawatir akan dianggap kuno dan tidak popular. Ini lah yang menjadi hambatan siswa remaja untuk dapat mengapresiasi kekayaan budayanya - ini dibutuhkan tekad dan kontrol diri pada remaja untuk menampilkan minat dan ketertarikan yang melawan dari arus atau stereotip umum yang berkembang diantaranya. Maka dari itu siswa yang mampu mengapresiasi kekayaan budaya ia tidak akan mudah terjebak dan terpengaruh budaya asing yang tidak sesuai dengan jati dirinya, ia memiliki kematangan emosional dan kognitif untuk dapat berpikir objektif dan memilih apa yang ia inginkan sekalipun bertentangan dengan pandangan umum. Ini menunjukkan keunggulan dalam diri siswa tersebut.

Komponen mengapreasi budaya bangsa yang menyusun karakter nasionalis dalam skala ini memiliki standar penilaian dan interpretasi yang dapat dijelaskan dalam tabel 8 dibawah ini.

Tabel 8.

Norma Hipotetik Komponen Apresiasi Budaya Bangsa

\begin{tabular}{lc}
\hline \multicolumn{1}{c}{ Klasifikasi } & Skor \\
\hline Sangat mampu mengapresiasi budaya & $\geq 12$ \\
bangsa & $\geq 10-11$ \\
Mampu mengapresiasi budaya bangsa & $\geq 6-9$ \\
$\begin{array}{l}\text { Cukup mampu mengapresiasi budaya } \\
\text { bangsa }\end{array}$ & $\geq 4-5$ \\
Tidak mampu mengapresiasi budaya & $<4$ \\
bangsa & \\
Sangat tidak mampu mengapresiasi & \\
budaya bangsa &
\end{tabular}

\section{Kategori Norma Hipotetik Komponen Taat Hukum}


Jurnal Psikologi Terapan dan Pendidikan

ISSN: $2715-2456$

Vol. 1, No. 2, November 2019, pp. 63-98

Komponen taat hukum dalam skala karakter nasionalis ini didefinisikan sebagai perilaku siswa yang mencerminkan sikap dan tindakan yang memahami dan memiliki kesadaran terhadap hukum yang karenanya individu memiliki kesetiaan terhadap hukum dan berupaya mentaati peraturan hukum tersebut sekecil apapun sanksinya ia akan menjunjung hukum yang berlaku dalam setiap tindak tanduknya dimanapun ia berada. Hukum dalam pengertian ini merupakan suatu peraturanyang memiliki konsekuensi lebih besar dari sanksi sosial (penghakiman masyarakat) yaitu apabila peraturan tersebut tidak dilakukan, dalam kata lain akan mendatangkan hukuman bagi individu yang melanggar aturan. Maka dari itu hukum yang dimaksud dalam pengertian ini adalah berbagai produk hukum yang dibuat dan berlaku dimana individu menetap atau tergabung. Hukum yang dimaksud juga merupakan peraturan-peraturan yang dibuat oleh suatu institusi atau individu yang berwenang memberikan aturan baik perintah ataupun larangan untuk mengatur perilaku masyarakatnya demi tercapai kehidupan yang adil, aman, damai, dan sejahtera.

Dalam pengertian tersebut mengandung dua makna sekaligus yaitu kesadaran terhadap hukum yang berarti pengetahuan terhadap wawasan hukum yang berlaku dan kemudian kepatuhan terhadap hukum yang berlaku tersebut berarti mengikuti dan melaksanakan apa yang diperintah dan menjauhi apa yang dilarang. Meskipun pada implementasinya kedua hal tersebut sering berjalan tidak beriringan, ini dikarenakan ego individu yang melaksanakan hukum tersebut. Oleh karena itu taat hukum merupakan aktualisasi dari kesadaran hukum masyarakat juga aspek yang mendasari seorang yang berkarakter nasionalis.

Komponen taat hukum merupakan komponen paling utama yang mengindikasikan karakter nasionalis. Hal tersebut sebagaimana dengan karakteristik yang mengindikasikan karakter nasionalis individu yaitu adanya kesadaran dan kepatuhan warga negara terhadap hukum yang berlaku. Ini dikarenakan Indonesia adalah negara merdeka dan berdaulat yang berasaskan hukum. Hukum di Indonesia berlandaskan pada Pancasila sebagai ideologi dan pedoman negara sehingga hukum di Indonesia harus senantiasa dijunjung dalam kehidupan sehari-hari. Ini karena hukum akan menjamin kesejahteraan dan kebaikan bersama bagi seluruh masyarakat atau bangsa.

Terlebih dengan ditunjukkannya nilai koefisien component loading yang sangat tinggi pada aitem rela berkorban serta cukup pada aitem taat hukum dan disiplin. Ini menegaskan jika sebagai bangsa dan warga negara Indonesia menjadi taat dan patuh terhadap peraturan adalah hal yang mutlak. Disisi lain kepatuhan dan ketaatan ini juga menunjukkan adanya suatu bentuk pengorbanan sebagai implikasi dari ketaatan dan kepatuhan yang dilakukan individu terhadap peraturan hukum. Hal ini sebagaimana nilai koefisien component loading yang menunjukkan rela berkorban merupakan aspek yang dominan dalam 
Jurnal Psikologi Terapan dan Pendidikan

ISSN: $2715-2456$

Vol. 1, No. 2, November 2019, pp. 63-98

komponen taat hukum siswa SMA. Hal tersebut dikarenakan untuk mematuhi peraturan-peraturan hukum yang berlaku dan menjadi warga yang taat hukum memang membutuhkan pengorbanan. Individu harus mampu menahan egonya dan patuh terhadap peraturan apapun - sekalipun ia merasa bahwa peraturan tersebut tidak penting, berlebihan, tidak masuk diakal, merugikan, terlalu mengikat atau mengatur, ataupun ketika individu tidak sedang di awasi atau justru karena individu merupakan pribadi yang senang melanggar peraturan dan tidak suka dikontrol terhadap aturan apapun. Individu yang mampu melawan egonya untuk menentang atau melanggar peraturan hukum apapun bentuknya merupakan suatu bentuk pengorbanannya bahwa ia berusaha mematuhi peraturan-peraturan. Terlebih pada masa remaja yang mana berada pada tahapan menilai dan mengevaluasi berbagai nilai-nilai dan peraturan yang ada disekitarnya. Terhadap peraturan yang memiliki sanksi longgar, tidak terawasi, atau menurutnya tidak penting, berlebihan dan tidak masuk diakal pasti akan dilanggar dan ditentang. Maka dari itu menjadi taat hukum bagi siswa SMA merupakan suatu bentuk pengorbanan mereka sebagai warga negara yang baik.

Rela berkorban, taat hukum, dan disiplin merupakan unsur-unsur yang saling berkaitan dalam membentuk dan mengindikasikan ketaatan individu terhadap hukum yang berlaku. Rela berkorban mengandung pengertian kesediaan dan kerelaan individu untuk memberikan atau melakukan sesuatu hal, sekalipun itu memberikan ketidaknyamanan dan kerugian baik material maupun immaterial terhadap dirinya - namun ia memiliki keiklasan dalam memberikan atau melakukannya. Kerelaan yang dilakukan semata-mata demi kebaikan orang lain terlebih untuk menjamin keseimbangan dan keselarasan dalam kehidupan berbangsa dan bernegara. Dalam ketaatan terhadap hukum ini kerelaan berkorban dicerminkan dalam sikap dan tindakan individu yang setia terhadap peraturan hukum tersebut dimanapun ia berada, dan apapun produk peraturan hukum tersebut serta apapun konsekuensinya ia akan menjunjung tinggi peraturan tersebut tanpa melanggarnya. Ini merupakan sikap dan tindakan dimana individu memiliki kesadaran dan kerelaan untuk menghormati hukum tersebut, melakukan dan melaksanakan apa yang diperintahkan dan menjauhi apa yang dilarang.

Kerelaan untuk patuh terhadap hukum yang berlaku merupakan suatu bentuk penerimaan terhadap hukum yang berarti pula individu memiliki pengetahuan serta wawasan terhadap peraturan sehingga mampu mengimplementasikan peraturan tersebut dalam kehidupan sehari-hari. Ini menunjukkan bahwa kerelaan berkorban dalam aspek taat hukum berarti kesediaan untuk menjalankan aturan-aturan hukum yang berlaku dengan kesadaran tinggi dan sepenuh hati. Terlebih ketaatan hukum pada dasarnya bersifat mengikat dan dipaksakan. Ini karena struktur hukum menurut Hasibuan (2016) berbasiskan kewajiban dan bukan lah diatas komitmen. Ini dikarenakan pembuatan hukum di suatu wilayah 
Jurnal Psikologi Terapan dan Pendidikan

ISSN: $2715-2456$

Vol. 1, No. 2, November 2019, pp. 63-98

dimaksudkan untuk mengatur warga masyarakatnya untuk berperilaku tertib dan teratur untuk menciptakan tatanan kehidupan yang adil, tertib dan sejahtera disuatu wilayah.

Terlebih individu yang mendiami setiap wilayah memiliki pola perilaku, kepercayaan, nilai, ide dan harapan yang berbeda sehingga mempengaruhi sikap dan tindakan mereka terhadap peraturanperaturan yang berlaku. Begitu pula dengan Indonesia merupakan negara yang heterogen dengan berbagai suku-suku budaya yang tersebar diseluruh Indonesia memiliki nilai-nilai norma dan kepercayaan yang berbeda-beda satu sama lain. Oleh karena itu hukum yang mengikat dan mengatur secara ketat keseluruhan rakyat Indonesia sangat diperlukan sehingga hukum dapat menjadi pedoman atau standar masyarakat dalam berperilaku. Maka dari itu peraturan hukum memang memiliki muatan dipaksakan agar ditaati oleh seluruh masyarakat. Meskipun pada pelaksanaannya peraturan hukum dapat terpecah atau di Indonesia terdesentralisasi pada peraturan pusat yang berlaku nasional dan peraturan daerah yang berlaku didaerah tertentu saja, namun semua itu merupakan wujud sistem hukum yang berlaku di Indonesia yang wajib untuk ditaati. Mentaati setiap hukum baik yang berlaku nasional ataupul lokal adalah wujud ketaatan warga masyarakat terhadap hukum. Oleh karena itu peraturan hukum yang dibuat ini menjadi kewajiban moral bagi masyarakatnya untuk taat dan patuh terhadap hukum.

Taat terhadap hukum tidak dapat dipisahkan dari kesadaran masyarakat terhadap hukum. Ini seperti pernyataan Ahmad Ali (Kamaruddin, 2016) bahwa untuk membangun kesadaran hukum pada suatu kelompok atau masyarakat maka diperlukan adanya pengetahuan mengenai hukum, isi hukum, sikap terhadap hukum, dan pola perilaku hukum. Oleh karena itu individu atau masyarakat yang telah memiliki pengetahuan hukum ia akan berusaha bersikap kooperatif terhadap hukum yang berlaku dan berperilaku yang tidak melanggar etika ataupun aturan. Ini seperti yang dijelaskan Ewick dan Silbey (Achmad, 2009) dimana individu yang memiliki kesadaran hukum adalah individu-individu yang dapat memahami hukum dan institusi-institusi hukum - dimana mereka memiliki pemahaman-pemahaman yang memberikan makna kepada pengalaman dan tindakan orang-orang. Dalam kata lain kesadaran hukum merupakan suatu bentuk "tindakan" atau perilaku dan bukan sekedar aturan norma atau asas. Ini menegaskan bahwa peran hukum bukan hanya sebagai otoritas yaitu menjadi peraturan yang memiliki kekuatan hukum yang mengikat dan memaksa setiap masyarakatnya namun hukum juga berperan sebagai pembentuk perilaku yang merujuk pada menciptakan masyarakat yang berkarakter sehingga semestinya dilaksanakan penuh kesadaran dan kesukarelaan tanpa paksaan.

Disisi lain disiplin merupakan implikasi lain yang mengikuti ketaatan individu terhadap hukum. Disiplin menurut KBBI online - merupakansuatu bentuk ketaatan (kepatuhan) kepada peraturan (tata tertib dan sebagainya). Disiplin merupakan aktualisasi dari ketaatan hukum individu. Individu yang 
Jurnal Psikologi Terapan dan Pendidikan

ISSN: $2715-2456$

Vol. 1, No. 2, November 2019, pp. 63-98

disiplin berarti ia mengetahui dan memahami peraturan yang berlaku disekitarnya sehingga dengan kesadaran penuh menerima dan melaksanakannya sebagai sebuah bentuk ketaatan terhadap hukum.Lebih daripada itu individu yang disiplin merupakan individu yang memiliki kontrol diri yang tinggi sehingga ia dapat menjalankan setiap aturan, perintah, dan kewajibannya dengan baik dan penuh kesadaran sehingga dapat menjalankan kehidupan dengan penuh keteraturan dan ketaatan terhadap hukum disekitarnya.

Komponen taat hukum merupakan komponen dengan koefisien muatan faktor tertinggi dalam penyusunan karakter nasionalis ini, sehingga dapat disimpulkan taat hukum menjadi aspek dominan yang menentukan karakter nasionalis seseorang. Dalam implementasinya ketaatan terhadap hukum memang sangat sulit dilakukan, sehingga taat hukum dapat disandingkan dalam pengertiannya namun berbeda dalam implementasinya. Ini karena seseorang yang sadar hukum belum tentu memiliki ketaatan terhadap hukum - terlebih jika melanggar hukum dapat memberikan keuntungan yang lebih besar terhadap dirinya baik itu dari segi material maupun immaterial. Perilaku opurtunis tersebut terlebih jika dilakukan dengan melawan hukum maka akan berpotensi untuk merugikan kepentingan orang banyak. Maka dari itu taat hukum adalah aspek penting yang harus dimiliki oleh bangsa yang nasionalis. Komitmen untuk patuh dan mentaati peraturan harus dibangun oleh masyarakat dan aparatur penegak hukum agar tercipta budaya hukum yang adil dan ideal bagi seluruh masyarakat yang menempati suatu wilayah.

Taat hukum memang mencakup aspek peraturan dengan cakupan yang besar yaitu berlaku secara nasional dan lokal, namun peraturan juga berlaku di institusi manapun individu berada. Pada siswa SMA mereka berada pada institusi seperti keluarga, sekolah, tempat kursus, tempat beribadah lingkungan tempat tinggal sebagai lingkungan hukum kecil serta kota, provinsi dan negara sebagai lingkungan hukum yang lebih besar. Maka dari itu peraturan bagi siswa SMA berlaku bahkan di lingkungan atau institusi yang memberikan sanksi kecil hukum sekalipun. Dalam hal ini siswa yang taat hukum berarti ia mampu mematuhi peraturan yang ada dirumah, disekolah, di tempat beribadah, dan dimanapun individu bernaung disuatu institusi yang memiliki peraturan mengikat.

Ketaatan terhadap hukum pada individu tidak lepas dari adanya kewajiban moral untuk mentaati dan mematuhi hukum tersebut. Disisi lain terbentuknya ketaatan hukum tidak lepas dari kesadaran hukum yang berarti pengetahuan dan pemahamam individu terhadap hukum - maka dari itu perkembangan ketaatan dan kepatuhan terhadap hukum individu tidak terlepas dari perkembangan kognitif dan moral individu. Disamping itu ketaatan terhadap hukum juga dipengaruhi oleh nilai-nilai yang dipercaya disetiap kepercayaan, terlebih pada negara yang berasas pada ketuhanan - maka nilai-nilai keagamaan memberikan kontrol yang kuat dalam perilaku individu didalam masyarakat sebagaimana yang diatur dalam kepercayaan agamanya. 
Jurnal Psikologi Terapan dan Pendidikan

ISSN: $2715-2456$

Vol. 1, No. 2, November 2019, pp. 63-98

Pada siswa remaja ketaatan terhadap hukum ini berkembang pada tahapan empat perkembangan moral Kohlberg (Santrock, 2014) - dimana pada tahapan ini remaja telah memiliki pemahaman terhadap keteraturan sosial, hukum, keadilan, dan tugas. Ini membuat remaja memiliki keyakinan bahwa agar komunitas dapat bekerja secara efektif maka komunitas perlu dilindungi oleh hukum yang harus ditaati oleh para anggotanya.

Meskipun menurut Hurlock (2014) remaja sejatinya harus mencapai tahapan perkembangan moral pasca konvensional yang berarti pengembangan kelenturan terhadap hukum dan suara hati - maka remaja yang mencapai tingkat moral pasca konvensional akan memilih melakukan tindakan sesuai suara hati. Dalam implementasinya ketaatan terhadap hukum yang berlaku disuatu wilayah memiliki konsekuensi mutlak untuk ditaati karena fungsi dan peran dari penciptaan hukum tersebut dibuat untuk menciptakan kehidupan yang menjamin keadilan dan kesejahteraan masyarakat. Oleh karena itu dalam situasi yang berhadapan pada dilema hukum yang memiliki implikasi besar terhadap kepentingan orang banyak, bangsa bahkan negara - telah sewajarnya untuk taat terhadap hukum dan menjunjung hukum yang berlaku. Ini seperti yang diungkapkan oleh Rosana (2014) bahwa ketaatan terhadap hukum pada hakikatnya adalah kesadaran dan kesetiaan masyarakat terhadap konsekuensi hidup bersama dimana kesetiaan terhadap hukum diwujudkan dalam bentuk perilaku riil patuh terhadap hukum. Terlebih hukum yang berlaku pada suatu wilayah bahkan negara diciptakan dengan tujuan tertentu terutama melindungi masyarakatnya. Menaati hukum berarti turut pula melindungi hak warga negara lainnya.

Sementara itu dalam kehidupan memang terdapat situasi yang menuntut kelenturan moral. Situasi ini adalah ketika berhadapan pada isu-isu atau kepentingan kemanusiaan dan peraturan yang tidak mengakomodasi keadilan dan kesejahteraan bagi masyarakat sehingga memungkinkan pelanggaran moral untuk menjamin kesejahteraan masyarakat tersisih tersebut tepat dilakukan. Pada isu kedua tersebut terlihat dari peraturan beberapa negara yang tidak mengakomodir perbedaan terhadap warga negaranya ini biasanya terkait masyarakat yang bukan berasal dari etnis tanah airnya atau kelompok pemeluk agama tertentu yang tidak sesuai diwilayahnya (negara yang tidak toleran terhadap imigran atau masyarakat minoritas). Maka dari itu kelenturan terhadap hukum dalam hal ini tepat berlaku. Hal tersebut sekaligus menunjukkan jika terdapat peraturan negara yang bersifat tidak absolut - artinya memiliki kemungkinan untuk dilanggar atau tidak ditaati.

Namun sejatinya pada permasalahan-permasalahan tertentu - terlebih terkait yang berurusan dengan nilai kemanusiaan individual adalah benar dilakukan karena biasanya tidak memiliki konsekuensi hukum dan bukanlah suatu bentuk penentangan terhadap peraturan yang berkaitan dengan kenegaraan. Maka dari itu dibutuhkan kemampuan berpikir yang kritis, logis, dan idealis disatu sisi sehingga dapat 
Jurnal Psikologi Terapan dan Pendidikan

ISSN: $2715-2456$

Vol. 1, No. 2, November 2019, pp. 63-98

berlaku bijak, tanpa meninggalkan kewajiban untuk taat, patuh dan menjunjung hukum yang berlaku dimana ia tinggal.

Komponen taat hukum yang menyusun karakter nasionalis dalam skala ini memiliki standar penilaian dan interpretasi yang dapat dijelaskan dalam tabel 9 dibawah ini.

Tabel 9.

Norma Hipotetik Komponen Taat Hukum

\begin{tabular}{lc}
\hline \multicolumn{1}{c}{ Klasifikasi } & Skor \\
\hline Sangat taat terhadap hukum & $\geq 12$ \\
Taat terhadap hukum & $\geq 10-11$ \\
Cukup taat terhadap hukum & $\geq 6-9$ \\
Tidak taat terhadap hukum & $\geq 4-5$ \\
Sangat tidak taat terhadap hukum & $<4$ \\
\hline
\end{tabular}

\section{Kategori Norma Hipotetik Komponen Unggul dan Berprestasi}

Komponen unggul dan berprestasi yang menyusun skala karakter nasionalis ini didefinisikan sikap dan tindakan siswa yang mencerminkan upaya dan usaha untuk menjadi pribadi yang cakap, terampil, dan bahkan terbaik dalam berbagai aspek bidang domain kehidupan baik yang berkaitan dengan ilmu pengetahuan maupun kemampuan atau kompetensi sosial dalam kehidupan sehari-hari. Dalam definisi ini mengandung makna untuk menjadi terbaik diantara yang lain dengan berusaha menjadi unggul dibidang pengetahuan yang menghasilkan ilmu atau produk yang bermanfaat bagi kepentingan ilmu pengetahuan dan berguna bagi orang banyak juga bermakna menjadi pribadi dengan kemampuan interpersonal (kompetensi sosial) yang baik sehingga dapat mewujudkan hubungan dan terlibat dalam situasi sosial yang memuaskan. Ini dikarenakan untuk menjadi pribadi yang unggul baik dalam bidang pengetahuan maupun situasi sosial bukanlah hal yang mudah. Keduanya membutuhkan keinginan dan usaha yang sungguh-sungguh sehingga memberikan hasil dan bukti atas apa yang mereka upayakan baik berupa penghargaan maupun pengakuan. Ini juga menunjukkan jika aspek unggul dan berperilaku menunjukkan unsur kecerdasan kognitif dan emosional individu.

Komponen unggul dan berprestasi juga menjadi komponen utama yang penting yang mengindikasikan adanya karakter nasionalis pada diri seseorang. Hal tersebut ditunjukkan dengan koefisien muatan faktor yang sangat baik pada aitem unggul dan berprestasi serta koefisien muatan faktor yang baik pada aitem menjaga kekayaan budaya bangsa. Maka dari itu pribadi unggul dan berprestasi dalam karakter nasionalis siswa SMA di Indonesia adalah mereka yang memiliki keinginan untuk menjadi pribadi yang unggul dan berprestasi dalam bidang apapun serta senantiasa berupaya untuk menjaga kekayaan budaya bangsa. Hal ini sesuai hasil analisis komponen pada karakter nasionalis siswa 
Jurnal Psikologi Terapan dan Pendidikan

ISSN: $2715-2456$

Vol. 1, No. 2, November 2019, pp. 63-98

SMA dimana tersusun dari aspek unggul dan berprestasi serta menjaga kekayaan budaya bangsa sebagai observed variables-nya.

Menjadi pribadi yang unggul dan berprestasi merupakan bentuk perjuangan bangsa Indonesia kini dalam mengembangkan, memajukan, mengharumkan, dan mensejahterakan bangsa dan negaranya. Kemajuan dan kesejahteraan negara hanya akan dapat tercapai ketika bangsa Indonesia memiliki karakter unggul dan berorientasi prestasi. Ini karena karakter tersebut akan menjadi individu menjadi pribadi yang kompetitif, memiliki tekad, dan tujuan sehingga senantiasa berusaha untuk bergerak maju (progresif) dalam mencapai tujuannya yang mana ini akan berimplikasi pada kemajuan dan kesejahteraan bangsa dan negara Indonesia sendiri.Selain itu menjadi individu yang unggul dan berprestasi mencirikan individu yang cerdas, kreatif, dan terampil sehingga ia mampu menggunakan kemampuannya untuk mempertahankan dan melestarikan kebudayaan bangsanya.

Individu yang berorientasi pada prestasi akan senantiasa berupaya dengan penuh perjuangan dan kerja keras yang mana membutuhkan energi yang besar, sehingga ketika individu mampu menaklukkan tantantangan untuk menjadi berprestasi maka ia telah menunjuk kualitas keunggulan diri dalam dirinya. Ini dikarenakan setiap manusia merupakan individu yang unik, mereka memiliki potensi dan keterbatasan masing-masing yang berbeda-beda pula. Seperti kata pepatah setiap individu tidak dapat menjadi yang terbaik dalam segala bidang, namun individu dapat melakukan dan mengupayakan yang terbaik yang ia bisa - terlebih jika itu memberikan manfaat dalam kehidupan sosial.

Disisi lain individu yang unggul dan berprestasi memiliki keadaan mental dan jasmani yang sehat dan kuat, memiliki ketekunan, kegigihan, kesiapan, kepecayaan diri, tujuan, dan fokus dalam melakukan sesuatu. Ini menunjukkan kualitas lain dari individu yang berorintasi pada keunggulan dan berprestasi. Mereka tidak melakukan sesuatu secara asal-asalan melainkan dengan sepenuh hati dan tanggung jawab sehingga tidak akan melakukan sesuatu setengah-setengah melainkan selalu berupaya untuk menyelesaikan tugas atau tantangan tersebut dan mampu untuk menanggulangi rasa pasrah dan ingin menyerah untuk mengakhiri apa yang telah dimulai. Selain itu pribadi yang unggul dan berprestasi senantiasa memiliki hati yang besar untuk menerima kekalahan dan mengakui kemampuan dan keberhasilan serta kebaikan orang lain. Ini dikarenakan setiap individu memiliki potensi yang berbedabeda yang mengantarkannya menjadi pribadi yang terbaik pada bermacam-macam bidang tertentu pula. Namun sejatinya menjadi unggul dan berprestasi tidak serta merta selalu menjadi yang terbaik dan satusatunya - ketika individu telah menjadi pribadi yang berguna dan bermanfaat bagi sesamanya maka ia telah menunjukkan kualitas keunggulan dalam dirinya. 
Jurnal Psikologi Terapan dan Pendidikan

ISSN: $2715-2456$

Vol. 1, No. 2, November 2019, pp. 63-98

Kesadaran untuk melakukan yang terbaik dan menjadi pribadi yang bermanfaat bagi orang lain haruslah dimiliki oleh seluruh masyarakat terutama siswa yang masih memiliki ambisi untuk menjadi yang terbaik dan satu-satunya. Siswa seharusnya dapat memahami bahwa untuk menjadi unggul dan berprestasi tidak hanya berupaya melakukan beragam cara untuk mendapat dan menjadi yang terbaik dan satu-satunya hanya untuk mendapatkan pengakuan dari orang tertentu namun mengabaikan proses yang jujur. Menjadi individu yang unggul dan berprestasi sejatinya tidak membutuhkan penghargaan atau pengakuan khusus. Ini karena ketika individu telah menampilkan upaya untuk melakukan yang terbaik yang dilakukan secara jujur dan tulus semata hanya untuk melakukan dan memberikan yang terbaik dan bermanfaat terhadap individu lain - maka ia menunjukkan kualitas diri pribadi yang unggul dan berprestasi, karena sejatinya individu yang tulus dalam melakukan sesuatu ia akan lebih mudah dikenali dan diakui oleh orang lain.

Menjadi pribadi yang unggul dan berprestasi yang mencerminkan individu yang nasionalis turut pula berarti kemampuan individu untuk dapat menjaga kekayaan budaya bangsanya. Kedua aspek ini bukanlah hal terpisah dan sejatinya beriringan. Ini dikarenakan untuk dapat menjaga kekayaan budaya bangsa yang berarti keinginan dan kebersediaan untuk mempelajari, memahami, serta melestarikan kekayaan budaya bangsanya membutuhkan kemampuan kognitif dan kecakapan sosial agar individu dapat melaksanakannya. Terlebih dizaman yang modern dan global ini disaat semua kebudayaan asing mudah untuk masuk kedalam suatu negara maka dibutuhkan usaha lebih pula untuk menjadikan budaya bangsa sendiri tidak hilang, tetap berakar kuat dan lestari dibangsa sendiri bahkan dikenal dan diakui oleh dunia internasional. oleh karena itu kecakapan dan keterampilan individu ini akan sangat berperan dalam mengembangkan cara yang aktif, kreatif dan inovatif untuk menjaga dan melestarikan kekayaan budaya bangsa sehingga dapat menumbuhkan ketertarikan dan kepedulian pada masyarakat Indonesia lainnya untuk turut serta menjaga dan melestarikan kekayaan budaya bangsa tersebut. Ini akan memberikan efek berupa pengakuan terhadap kekayaan budaya tersebu dimata Internasional sehingga bangsa lain tidak dapat melecehkan atau bahkan mengklaim kekayaan budaya bangsa Indonesia sebagai kekayaan budaya bangsanya sendiri.

Aspek unggul dan berprestasi dalam karakter nasionalis siswa SMA ini merujuk pada karakter cerdas menurut Komalasari dan Saripudin (2015). Ini seperti yang dijelaskan Budimansyah (Komalasari \& Saripuddin, 2015) bahwa setiap individu memiliki kecerdasan dalam taraf tertentu yang tercermin dari perilakunya yang aktif, objektif, analitis, aspiratif, kreatif, dan inovatif, dinamis dan antisipatif, berpikiran terbuka dan maju, serta mencari solusi. Oleh pribadi yang cerdas maka kecerdasan tersebut dapat diimplementasikan dalam berbagai bidang kehidupan ideologi, politik, ekonomi, sosial, budaya, agama, 
Jurnal Psikologi Terapan dan Pendidikan

ISSN: $2715-2456$

Vol. 1, No. 2, November 2019, pp. 63-98

dan pertahanan keamanan, serta dalam berbagai bidang wilayah kehidupan pribadi, keluarga, sosial, kewarganegaraan dan global. Pernyataan tersebut menunjukkan jika aspek unggul dan berprestasi tidak hanya memiliki dua sisi kecerdasan - kognitif dan emosional saja, namun juga menegaskan jika aspek ini tidak hanya berlaku dalam dunia ilmu pengetahuan saja namun pada berbagai bidang kehidupan berbangsa dan bernegara lainnya.

Dalam implementasinya aspek ini dapat dicontohkan dengan sikap siswa yang mampu dan selalu berlaku jujur dalam melakukan apapun, mengerjakan tugas yang diberikan oleh guru dengan sebaikbaiknya tanpa mengeluh, mengikuti eksakulikuler atau kursus yang dapat mengembangkan kecakapan dan kompetensi diri. Siswa juga memiliki semangat dan terpacu untuk mengikuti perlombaan yang dapat mengasah kemampuan dirinya, meningkatkan prestasi diri dengan menempuh pendidikan sebaik mungkin, terlibat dalam aksi sosial baik yang berkaitan dengan pelestarian kekayaan budaya, alam dan lingkungan Indonesia atau dengan menjadi tim sukarelawan bencana alam dan kemanusiaan dan lain sebagainya.

Komponen unggul dan berprestasi yang menyusun karakter nasionalis dalam skala ini memiliki standar penilaian dan interpretasi yang dapat dijelaskan dalam tabel 10 dibawah ini.

Tabel 10.

Norma Hipotetik Komponen Unggul dan Berprestasi

\begin{tabular}{lc}
\hline \multicolumn{1}{c}{ Klasifikasi } & Skor \\
\hline Sangat unggul dan berprestasi & $\geq 7$ \\
Unggul dan berprestasi & $\geq 6$ \\
Cukup unggul dan berprestasi & $\geq 4-5$ \\
Tidak unggul dan berprestasi & $\geq 3$ \\
Sangat tidak unggul dan berprestasi & $<2$ \\
\hline
\end{tabular}

\section{KESIMPULAN}

Hasil kontruksi alat ukur psikologi karakter nasionalisme Siswa Menengah Atas memiliki properti psikometris yang baik dan memuaskan. Alat ukur ini menghasilkan 25 aitem pernyataan yang memiliki validitas dan reliabilitas yang baik. Dari hasil uji validitas faktorial principal component analysis didapatkan bahwa dari 9 komponen yang diprediksi oleh peneliti, aitem-aitem tersebut mengumpul pada 5 komponen utama pembentuk konstruk skala. Aitem-aitem tersebut mengumpul dengan komponen pembentuknya yaitu komponen cinta tanah air sebanyak 11 aitem, komponen menghormati keragaman budaya sebanyak 4 aitem, komponen apresiasi budaya bangsasebanyak 4 aitem, komponen taat hukum sebanyak 4 aitem serta komponen unggul dan berprestasi sebanyak 2 aitem. Nilai koefisien korelasi antar aitem dalam muatan faktor bergerak dari skor 0.411 sampai dengan 0.747 yang berarti aitem dapat merefleksikan dengan baik individu yang memiliki karakter nasionalis dan tidak. Berdasarkan hasil analisis korelasi komponen diketahui jika antar komponen pada konstruk skala karakter 
Jurnal Psikologi Terapan dan Pendidikan

ISSN: $2715-2456$

Vol. 1, No. 2, November 2019, pp. 63-98

nasionalis ini tidak saling mengikat, masing-masing komponen berdiri sendiri dan tidak saling mempengaruhi.

Hasil uji reliabilitas menggunakan metode Gutmann's memiliki koefisien 0.862 yang berarti skala ini memiliki nilai reliabilitas yang sangat baik serta alat ukur ini memiliki tingkat keterpercayaan yang tinggi. Penelitian selanjutnya diharapkan dapat melakukan penelitian terhadap individu dewasa seperti mahasiswa atau pekerja juntuk mengetahui dinamika konsep karakter nasionalisme pada individu dari berbagai tahapan perkembangan secara konkrit. Selain itu penelitian selanjutnya diharapkan dapat mengeksplorasi karakter nasionalis pada masyarakat dari berbagai latar belakang etnis budaya di Indonesia. Hal ini agar didapatkan dinamika karakter nasionalisme di tengah masyarakat Indonesia yang plural.

Dengan adanya skala karakter nasionalisme maka dapat membantu pemerintahan dalam mengukur, mengevaluasi karakter nasionalisme serta dapat dijadikan sebagai landasan dalam membuat kebijakan pemerintah baik berupa peraturan untuk menumbuhkan karakter nasionalisme pada masyarakat Indonesia.

\section{DAFTAR PUSTAKA}

Achmad, A. (2009). Menguak teori hukum (legal theory) dan teori peradilan (judicial prudence) termasuk interpretasi undang-undang (legisprudence). Jakarta: Kencana Prenada Media Group.

Agustian, M., Anindyta, P., \& Grace, M. (2018). Mengembangkan karakter menghargai perbedaan melalui pendidikan multikultural. Jurnal Bakti Masyarakat Indonesia, 1(2), 191-199.

Anggoro, W. J. \& Widhiarso, W. (2010). Konstruksi dan identifikasi properti psikometris instrumen pengukuran kebahagiaan berbasis pendekatan indegenous psychology: Studi multitraitmultimethod. Jurnal Psikologi, 37(2), 176-188.

Azwar, S. (2017). Penyusunan skala psikologi. Yogyakarta: Pustaka Pelajar.

Harrington, D. (2009). Confirmatory factor analysis pocket guide to social wirk research methods. New York: Oxford University Press.

Hasibuan, Z. (2016). Kesadaran hukum dan ketaatan hukum masyarakat dewasa ini. Justitia: Jurnal Ilmu Hukum dan Humaniora, 1(1), 78-92.

Hurlock, E. (2014). Psikologi perkembangan: Suatu Pendekatan sepanjang rentang kehidupan edisi kelima. Jakarta: Erlangga.

Josephson, M. (2002). Making ethical decisionsthe basic primer on using the six pillars of character to make better decisions and a better life. Los Angeles: Josephson Institute of Ethics.

Kamarudin. (2016). Membangun kesadaran dan ketaatan hukum masyarakat perspektif lawa enforcement. Jurnal Al-'Adl, 9(2), 143-157.

Periantalo, J. (2015). Validitas alat ukur psikologi aplikasi praktis. Yogyakarta: Pustaka Pelajar. 
Jurnal Psikologi Terapan dan Pendidikan

ISSN: $2715-2456$

Vol. 1, No. 2, November 2019, pp. 63-98

Kamus Besar Bahasa Indonesia. (2019, Juni 10). KBBI.kemdikbud.go.id/entri/disiplin.

Komalasari, K \& Saripudin, D. (2017). Pendidikan Karakter konsep dan aplikasi living values education. Bandung: Reflika Aditama.

Lickona, T. (2016). Mendidik untuk membentuk karakterbagaimana sekolah dapat mengajarkan sikap hormat dan tanggung jawab. Jakarta: Bumi Aksara.

Permanto, T. (2012). Perilaku nasionalistik masa kini dan ketahanan nasional: Penerapan perilaku nasionalistik masa kini. Yogyakarta: Mata Bangsa.

Kusumawardani, A., \& Faturochman. (2004). Nasionalisme. Buletin Psikologi. 12(2), 61-72.

Ratnasari, M. (2017). Proses penanaman sikap nasionalisme dalam pembelajaran ilmu pengetahuan sosial pada siswa kelas tingi SD Taman Muda Ibu Pawiyatan Yogyakarta tahun ajaran 2016/2017. Trihayu: Jurnal Pendidikan ke-SD-an, 3(3), 144-150.

Rosana, E. (2014). Kepatuhan hukum sebagai wujud kesadaran hukum masyarakat. Jurnal Tapis, 10(1), $1-25$.

Samani, M., \& Hariyanto. (2012). Konsep dan Model pendidikan karakter. Bandung: PT Remaja Rosdakarya.

Santrock, J. W. (2009). Remaja edisi 11 Jilid 1. Jakarta: Erlangga.

Tabachnick, B. G., \& Fidell, L. S. (2014). Using multivariate statistics sixth edition. Boston: Pearson

Yogeswaran, K., \& Dasgupta, N. (2014). Conceptions of national identity in a globalized world: Antecedents and consequences. European Review of Social Psychology. 25(1), 189-227. 